\title{
Il linguaggio dell'architettura funzionale e della memoria nel Parco del Retiro a Madrid
}

\author{
Davide Carleo \\ Martina Gargiulo \\ Luigi Corniello \\ Michelangelo Scorpio \\ Giovanni Ciampi \\ Pilar Chías Navarro
}

Abstract

\begin{abstract}
La ricerca presenta i risultati della campagna di rilievo architettonico e ambientale nel Parco del Retiro a Madrid, studiandone, attraverso il disegno di architettura, l'evoluzione storica e formale fino all'attuale configurazione. È risultato di notevole interesse ripercorrere, con l'ausilio di immagini d'archivio, le fasi salienti della costruzione attraverso personaggi e vicende di Palazzo. Di rilevante importanza nella conoscenza di tale evoluzione, è lo studio delle planimetrie storiche della città di Madrid e di come in esse si noti il cambiamento morfologico e topografico del Parco. Lo studio ha interessato la Estanque Grande, una prima vasca d'acqua utilizzata come serbatoio idrico sia per il Palazzo sia per il Parco, il Palacio de Velazquez, il Palacio de Cristal e la Cascada e il Bosque del Recuerdo, una collina realizzata nel 2004 a seguito dell'attentato terroristico di Madrid, con lo scopo di commemorare le 191 vittime della strage. Obiettivo finale dello studio è quello di documentare l'architettura del passato attraverso rilievi e modelli digitali, nonché di predisporre le basi per interventi di tutela e rigenerazione delle strutture e dei percorsi a verde.
\end{abstract}

Parole chiave

rilievo, modellazione, rappresentazione, Parco, Spagna.

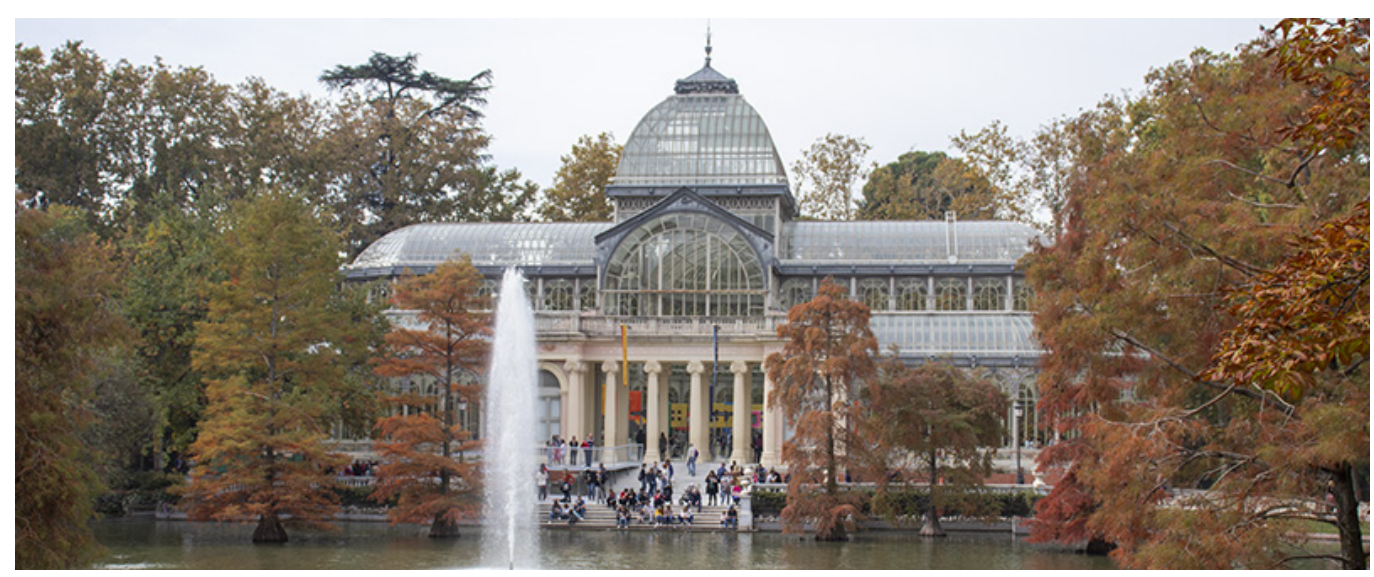




\section{Introduzione}

La ricerca intende porre l'attenzione sul Parco del Retiro a Madrid, e nello specifico sui sistemi vegetazionali e architettonici, studiandone, attraverso il disegno di architettura, l'evoluzione fino all'attuale configurazione. II periodo di costruzione risale al 1630, anno in cui furono fortemente volute dal re d'Austria alcune delle aree di cui ancora oggi il Parco è composto. Studi archivistici hanno reso possibile l'analisi della trasformazione formale e morfologica, in quella che sarebbe poi diventata, una delle aree più importanti della città. II progetto originario prevedeva una serie di architetture intorno a un Palazzo con un proprio giardino: oggi quel che resta dell'edificio originario è chiamato Casòn del Buen Retiro mentre il giardino, si è evoluto nel corso dei secoli. È risultato di notevole interesse ripercorrere, con l'ausilio di immagini d'archivio, le fasi salienti della costruzione attraverso personaggi e vicende di Palazzo. Di rilevante importanza nella conoscenza di tale evoluzione è lo studio delle planimetrie storiche della città di Madrid e di come in esse si noti il cambiamento morfologico e topografico del Parco. Nel 1620 fu costruita la Estanque Grande, una prima vasca d'acqua utilizzata come serbatoio idrico sia per il Palazzo sia per il Parco, successivamente trasformata in un luogo d'incontro tra i nobili nel quale svolgevano attività in acqua con barche. All'inizio del secolo successivo, intorno al I70 I, seguendo i dettami stilistici del Giardino Francese, fu progettato il Jardin del Parterre, modificato durante la Guerra d'Indipendenza. Con l'arrivo a Madrid della stirpe dei Borbone si aggiungono specie arboree e nuove aree che, solo nel 1767 Carlo III rese accessibili al pubblico a condizione di rispettare alcune regole e limiti territoriali esclusivi della corona. Nel XIX secolo la Guerra

Fig. I. II Parco del Retiro a Madrid, planimetria generale: 1) Casita del del Retiro, 3) ll Templete del Retiro, 3) la Estanque Grande, 4) il Palacio de Velazquez, 5) il Palacio de Bosque del Recuerdo.

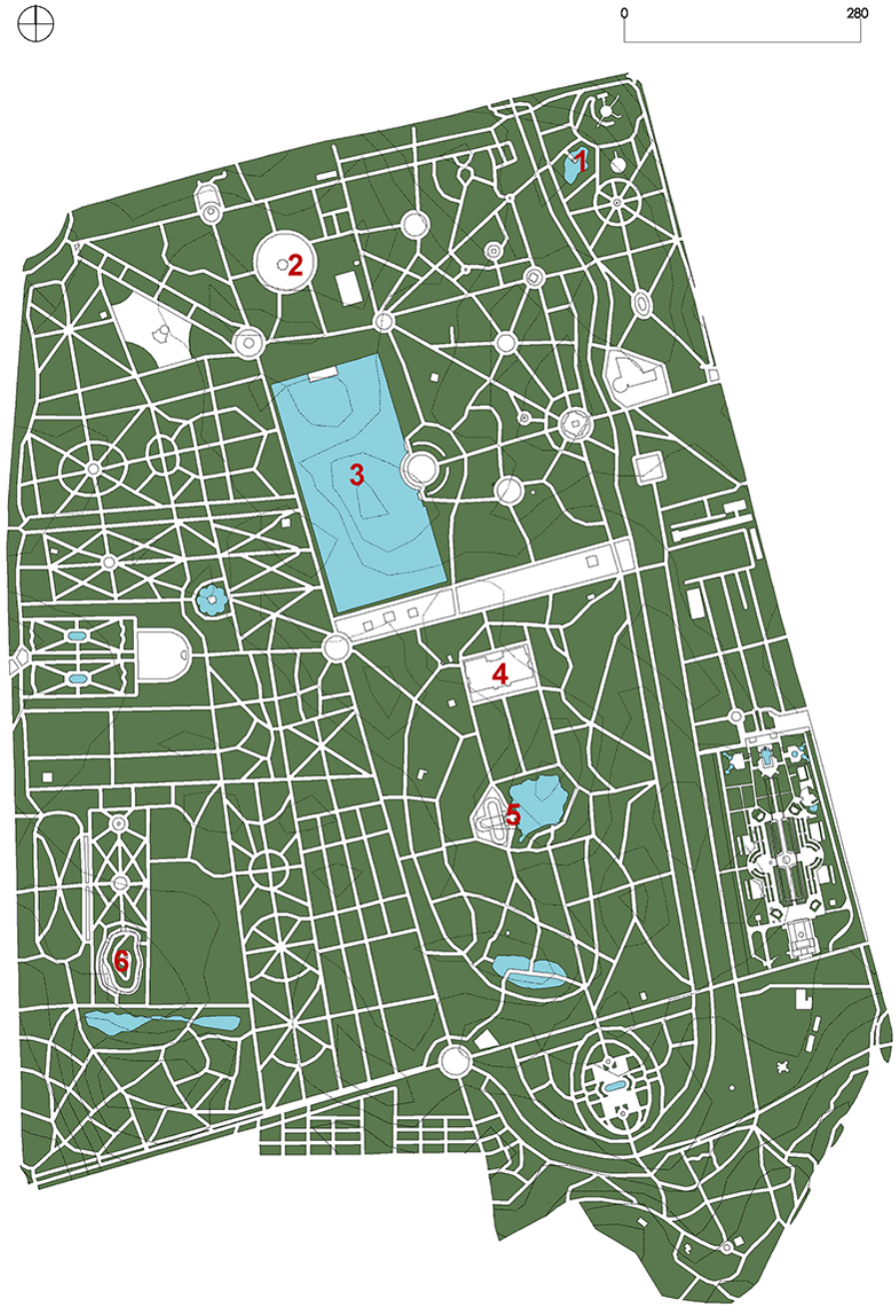


$\otimes$
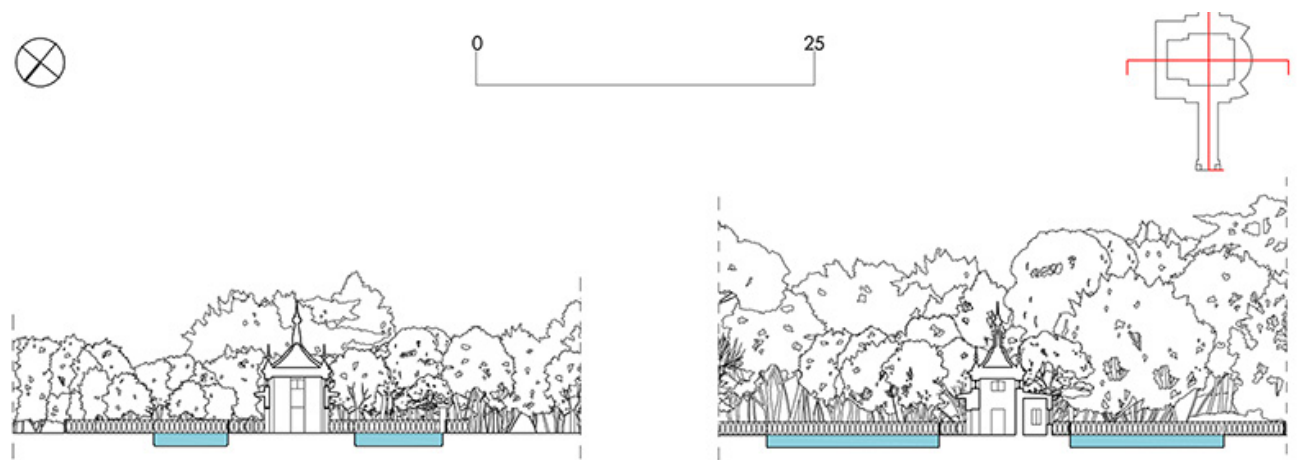

Fig. 2. II Parco del Retiro

a Madrid, la Casita del

Pescador, pianta delle

coperture, sezione A-A

(a sinistra), sezione B-B'

(a destra).

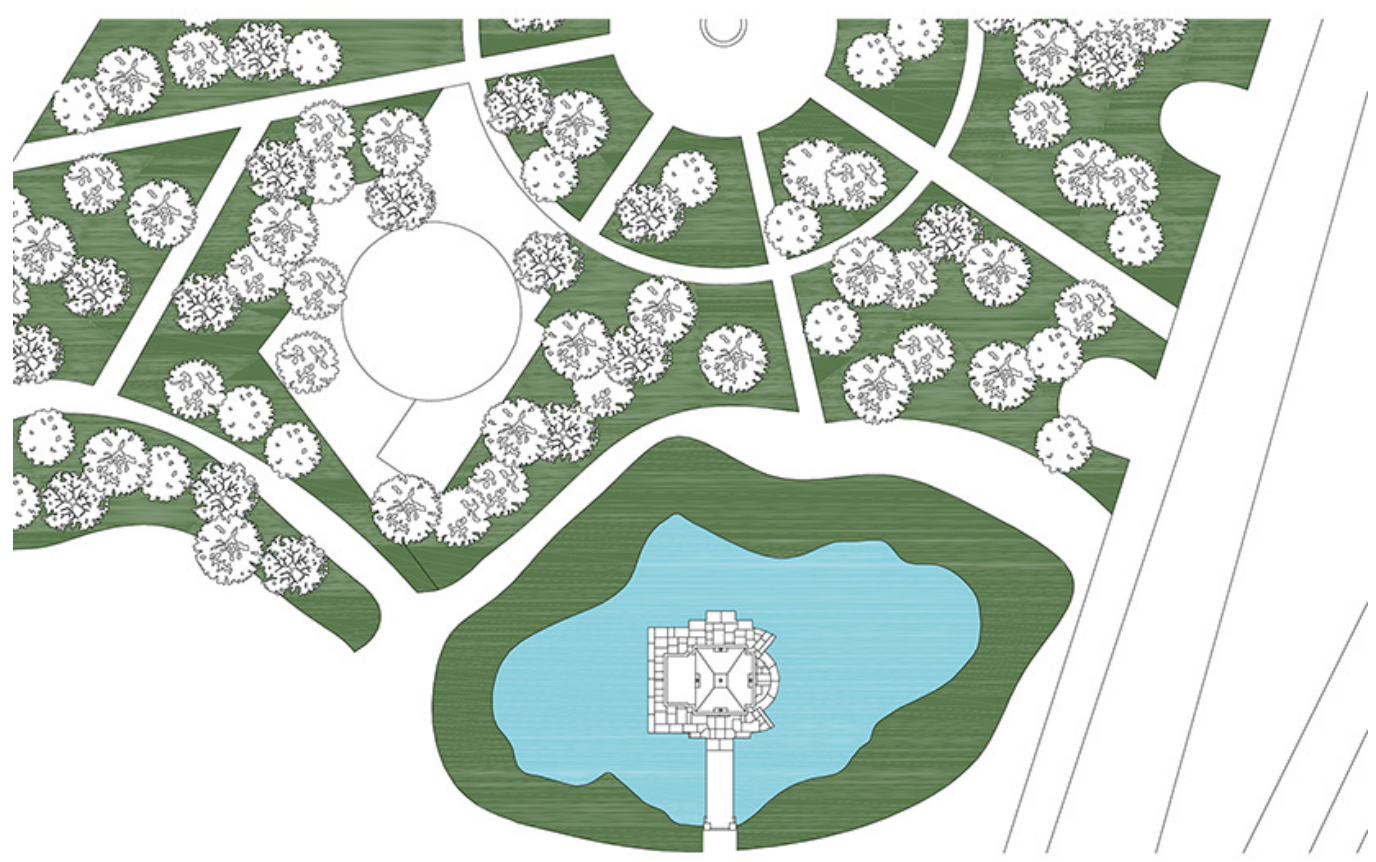

Fig. 3. II Parco del Retiro

a Madrid, la Casita del

Pescador, assonometria

dal basso.

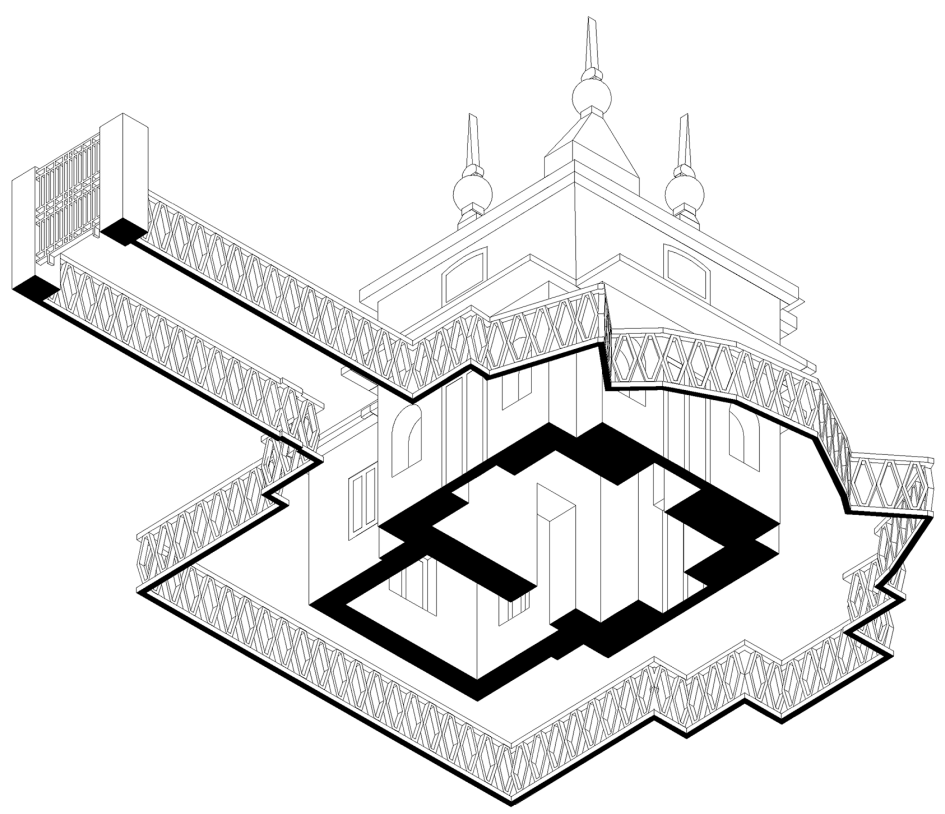


di Indipendenza causò notevoli danni al Parco ma sono numerose le tavole storiche legate a quell'epoca che illustrano l'intensa opera di restauro avvenuta con l'inserimento di ulteriori elementi architettonici. Successivamente la gestione del Parco passò sotto il controllo della Municipalità di Madrid che lo dichiarò Parco pubblico.

Negli ultimi anni del XIX secolo fu luogo designato per importanti esposizioni internazionali le quali richiesero l'aggiunta di una serie di padiglioni espositivi e spazi a verde attrezzato, quali, ad esempio, il Palacio de Velazquez e il Palacio de Cristal, ideato come serra e posto alla base di uno splendido salto d'acqua denominato la Cascada e, inizialmente utilizzato per l'irrigazione della vegetazione del Parco stesso. Fino ai primi decenni del $X X$ secolo, prima l'architetto José Urioste y Velada e successivamente l'architetto comunale Luis Bellido, si occuparono della realizzazione del nuovo recinto e la costruzione di nuove porte di ingresso.

\| XX secolo fu, poi, caratterizzato anche dalla costruzione di alcuni monumenti commemorativi tra cui quello dedicato ad Alfonso XII situato nel Estanque Grande e infine allo storico giardiniere Cecilio Rodriguez.

Di recente costruzione, invece, è il Bosque del Recuerdo, una collina realizzata nel 2004 a seguito dell'attentato terroristico di Madrid, con lo scopo di commemorare le 191 vittime della strage.

\section{II settore nord e le architetture originarie}

II rilievo delle architetture e dei sistemi a verde del Parco del Retiro a Madrid costituisce un processo di conoscenza di elementi ereditati dal passato e propone, uno studio sistemico, con un rilievo grafico e geometrico delle strutture. Attraverso una riflessione critica sull'architettura, mediante un'indagine grafica delle fonti disciplinari del disegno, con attenzione ai temi della forma, della struttura, dell'innovazione e della rappresentazione, si tende a porre, il disegno di alcuni documenti d'archivio e il rilievo dello stato attuale delle strutture e della vegetazione.

Lo studio presenta i risultati del rilievo eseguito tra il mese di ottobre del 2019 e il febbraio del 2020, tenendo conto dell'orientamento del Parco e seguendo il percorso che va da Nord verso Sud.

La Casita del Pescador, situata nell'area nord-est del Parco, fu costruita agli inizi del XIX secolo durante la monarchia di Fernando VII in seguito ai danneggiamenti dell'intero parco dovuti alla Guerra di Indipendenza. II Re propose la ricostruzione degli elementi distrutti e ne introdusse di nuovi per rilanciare il valore del Parco ma anche per esigenze personali. La Casita del Pescador, infatti, fu realizzata per i momenti liberi del Sovrano, come luogo di svago e sito in cui poter pescare. Nel corso degli anni ha subito diversi restauri, tra cui quello nel 1959 che ne mutò la destinazione d'uso in una biblioteca per conservare libri di giardinaggio. Per diversi anni abbandonata, agli inizi del 2000 è stata restaurata e attualmente ospita un centro di informazione per l'adozione di animali domestici. Il progetto originario realizzato dall'architetto Isidro González Velázquez, si estende per una lunghezza di circa 7 metri, 6 metri in larghezza e per un'altezza di 10 metri ed è circondato da un piccolo lago di origine artificiale. In facciata sono presenti stucchi rosati, ornamenti e dipinti in stile pompeiano e due nicchie per ogni lato dove erano presenti delle statue. Il corpo interno è articolato in una sala principale e un modesto locale laterale, i soffitti sono affrescati con motivi geometrici e figure allegoriche e sono presenti diversi ornamenti decorativi in stucco. L'accesso alla Casita avviene attraverso una passerella in legno con balaustra sospesa sull'invaso d'acqua. La copertura presenta un sistema tradizionale a guglia di zinco madrilena sormontata da una sfera di metallo. L'isolotto si trova in posizione centrale rispetto al lago profondo circa I metro e fino al $X X$ secolo la recinzione esterna era costituita da assi in legno mentre, alla fine della Prima Guerra Mondiale, fu sostituita con una maggiormente resistente in ferro battuto decorata con lo stesso motivo geometrico presente nella ringhiera della terrazza ma con altezza inferiore. 
Fig. 4. II Parco del Retiro a Madrid, il Templete del Retiro, pianta delle coperture, sezione $A-A^{\prime}$ (a destra).

$\oplus$
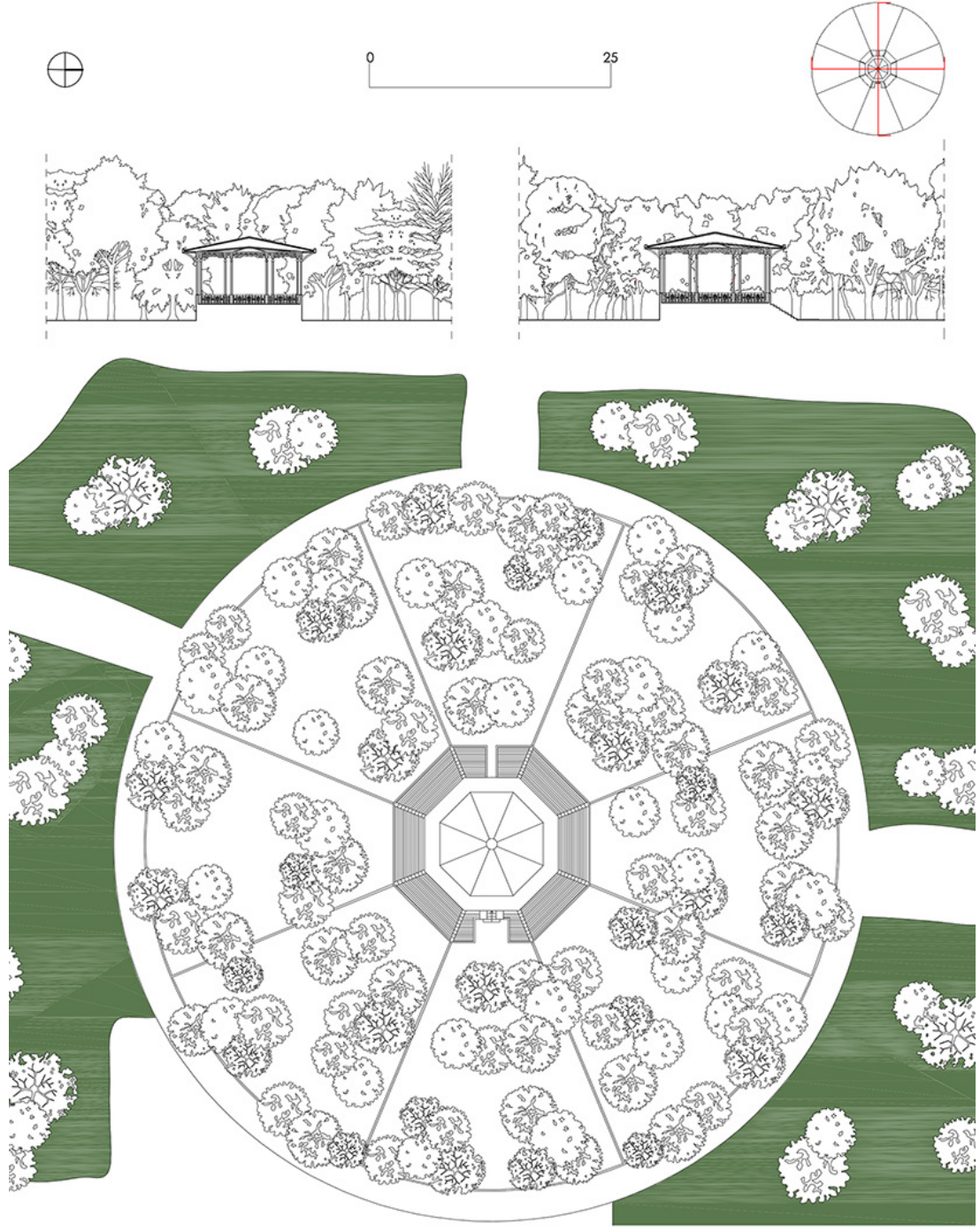

Fig. 5. II Parco del Retiro a Madrid, il Templete del

Retiro, assonometria dal

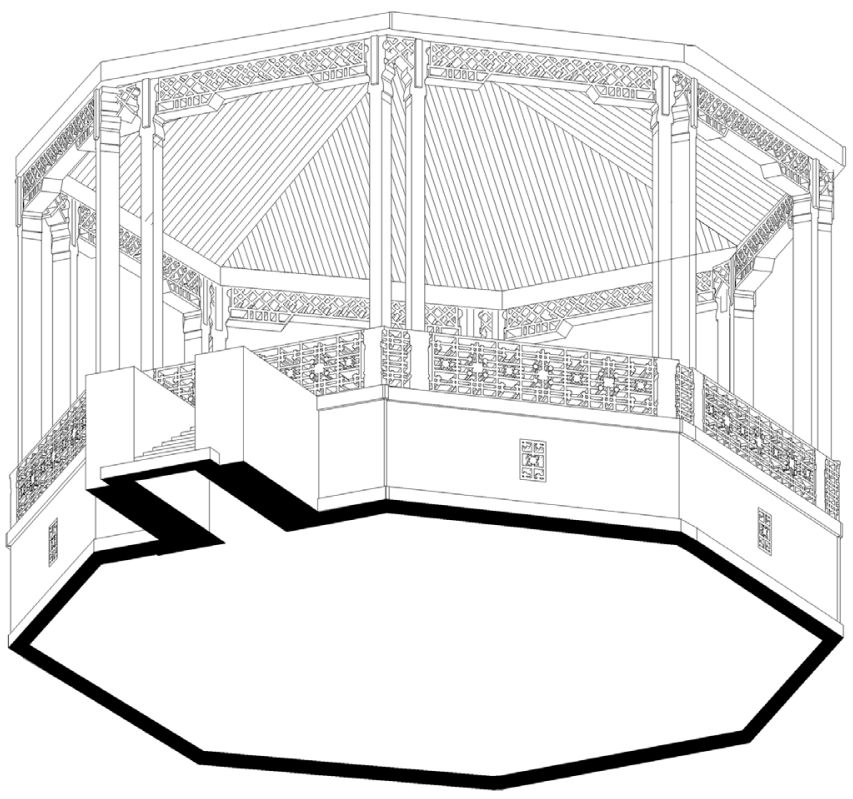


Nell'area nord del Parco è sito il Templete del Retiro, che fu costruito nel 1925 su commissione della Municipalità di Madrid con un progetto redatto dall'architetto Luis Bellido. La struttura è caratterizzata da una pianta ottagonale di 4,60 metri per lato, e un'altezza di circa 10 metri; il piano di calpestio è sito a una quota più alta rispetto al suolo al fine di amplificare il suono attraverso un sistema sotterraneo di pieni e vuoti. II paramento murario inferiore esterno è contrassegnato da una piccola apertura, chiusa da una grata ornamentale in ferro su ogni lato dell'ottagono, mentre nella parte posteriore, è presente una porta di dimensioni ridotte per garantire l'accesso per effettuare lavori di manutenzione. L'ottagono è circondando da una balaustra in ferro riccamente decorata e all'estremità di ogni lato è presente un pilastrino in ferro ornato che sorregge la copertura. Quest'ultima è realizzata in ferro mentre internamente è presente un rivestimento in doghe di legno tale da permettere una corretta amplificazione del suono. II Templete del Retiro trova esempi coevi di riferimento in vari Parchi e Giardini d'Europa con strutture realizzate a partire dall'inizio dell'Ottocento per esibizioni musicali. Analogamente costruiti e riportanti spesso la stessa forma per motivi relativi all'acustica, tali strutture rappresentano un elemento ricorrente.

Nel 1635, invece, fu completata la Estanque Grande realizzata da Cristóbal de Aguilera, e successivamente donata dal Duca di Olivares al Re Filippo IV. È stata concepita come una grande riserva d'acqua che potesse garantire l'approvvigionamento idrico sia al Palazzo
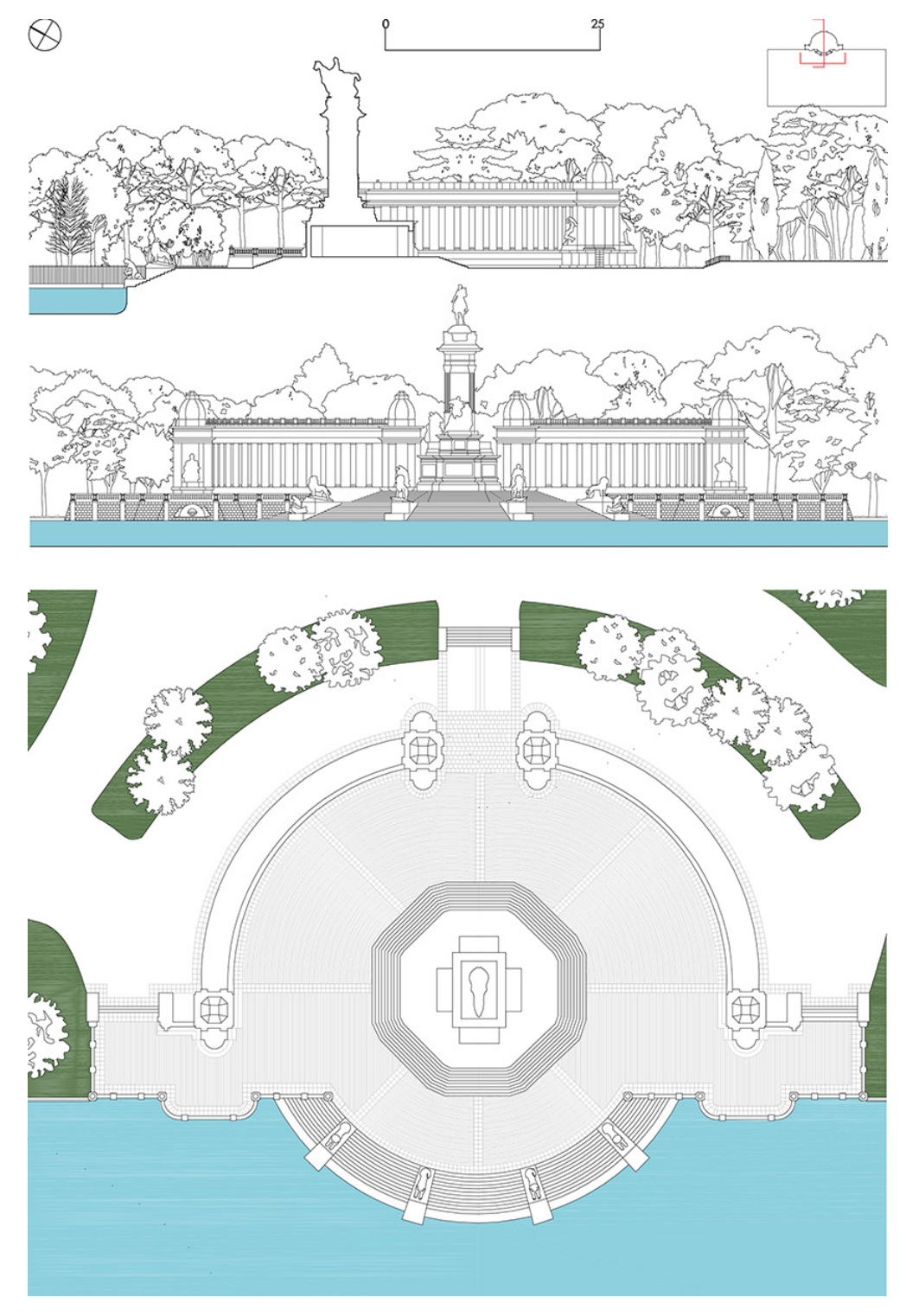
$\varnothing$
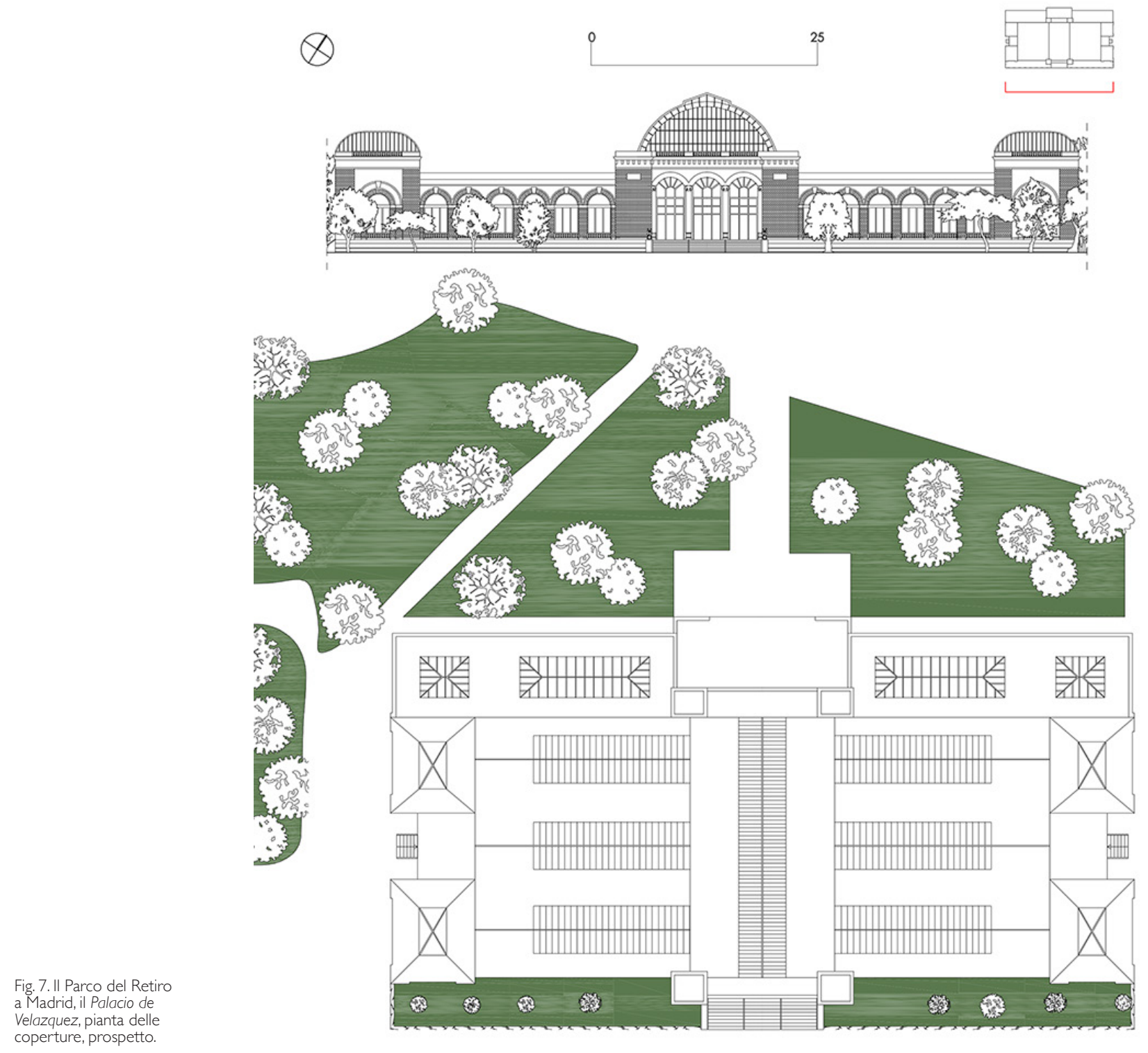

Fig. 8. II Parco del Retiro




Reale sia alle fontane dei giardini. Il progetto originario prevedeva, ai quattro lati della fontana, delle torri panoramiche con lo scopo di convogliare le acque e distribuire le stesse nelle varie aree del Parco. Durante la Guerra d'Indipendenza il Parco del Retiro fu utilizzato come quartier generale delle truppe napoleoniche e la Estanque Grande subì molteplici danni. Successivamente all'evento bellico Ferdinando VII recuperò lo stato originario dell'edificio e ne propose un rimaneggiamento stilistico a opera dell'architetto Isidro González Velázquez. A est, sul lato in cui attualmente si trova il Monumento ad Alfonso XIl, furono costruiti tre corpi decorati con motivi cinesi, a sud, fu costruita la Fontana Egizia e al centro della fontana principale una grande colonna con la statua di Ferdinando VII. L'intero complesso fu aperto al pubblico per volere della figlia Isabella II, con il relativo permesso alla navigazione. Successivamente, dopo gli anni della Rivoluzione, l'intero Parco passò a una gestione dalla municipalità e con esso anche la Estanque Grande. La struttura con una larghezza di circa I 25 metri, una lunghezza di 250 e una profondità massima di circa 1.80, è circondata dalla presenza da differenti specie di alberi popolati da una ricca varietà di fauna.




Fig. 10. II Parco del Retiro a Madrid, il Palacio de Cristal e la Cascada, sezione A-A' (in alto), sezione B-B' (in basso).

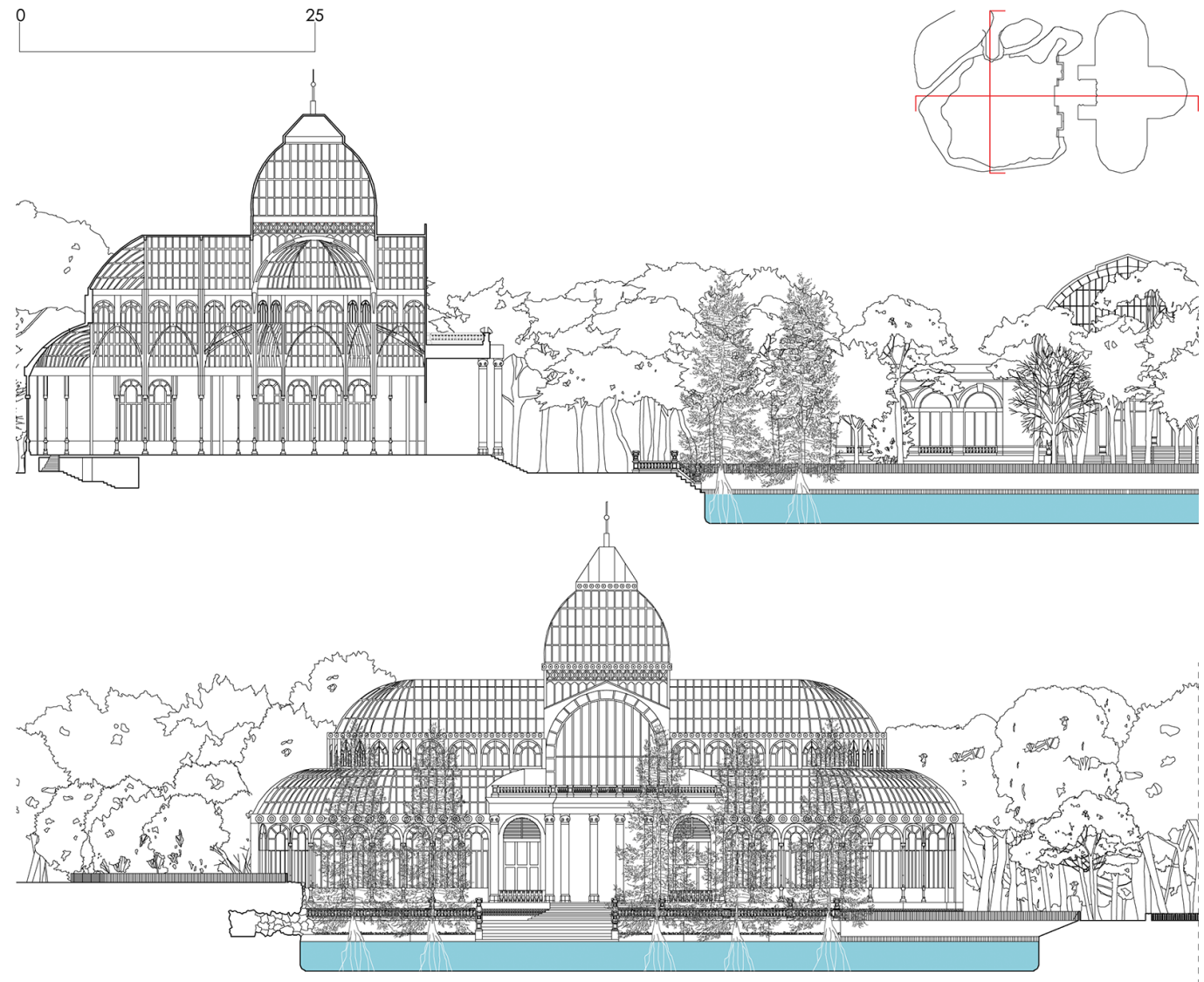

Fig. I I. II Parco del Retiro a Madrid, il Palacio de Cristal e la Cascada, assonometria dal basso.

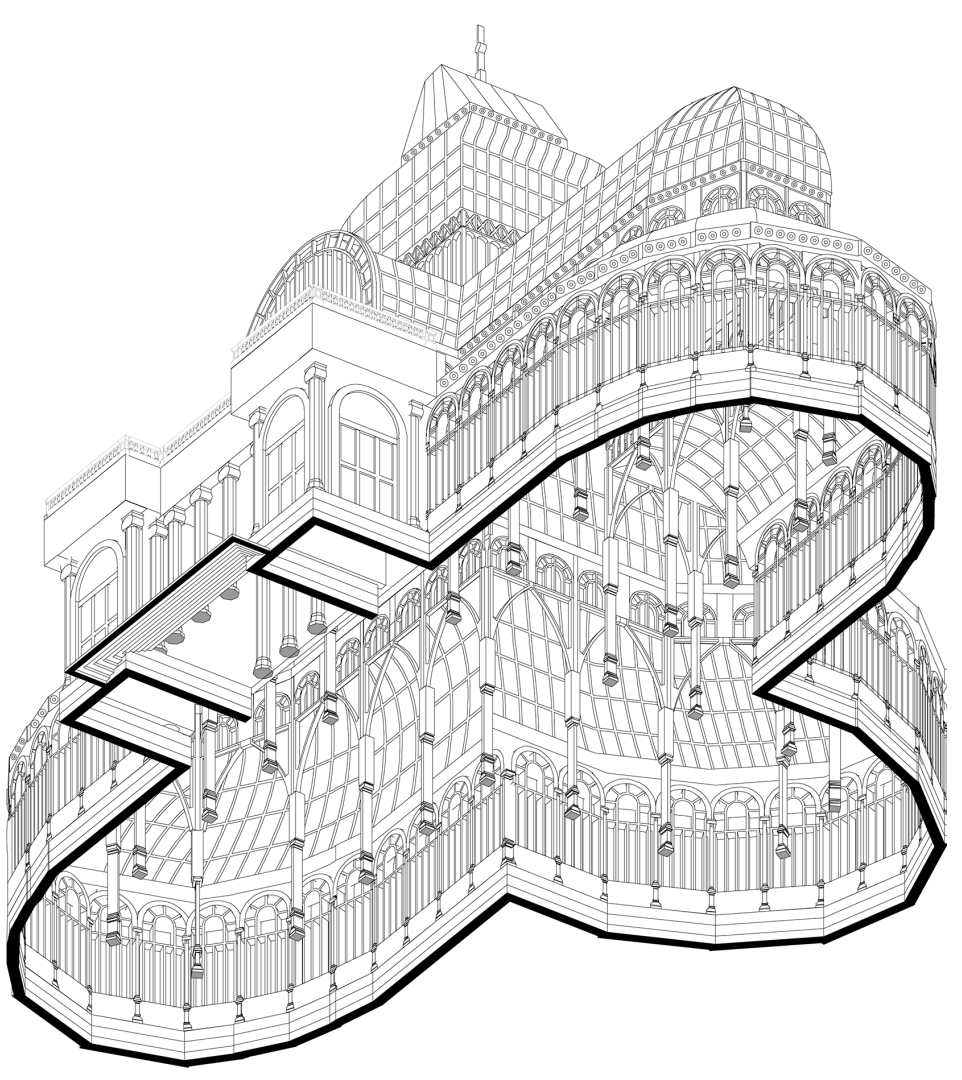




\section{II settore centrale e le architetture funzionali}

Nell'area centrale del Parco, è collocato il Palacio de Velazquez realizzato sotto il Regno di Alfonso XII nel I883, su progetto redatto dall'architetto Ricardo Velazquez Bosco con la direzione tecnica di Alberto del Placio mentre Daniel Zuloaga e Bernardo Asins ebbero il compito di costruire e assemblare la copertura in ferro e vetro. L'edificio fu costruito per l'Esposizione Internazionale del 1883 riguardante le ceramiche, i vetri e le acque naturali, è di forma rettangolare con il lato più lungo rivolto verso Sud di circa 80 metri mentre il lato minore di circa 30 per un'altezza di circa 20 metri. Le facciate sono caratterizzate da muratura di diverse tonalità di colore, ceramiche con motivi geometrici e vegetali per ornamentare le arcate, stucco per le cornici, ferro per la struttura delle cupole e infine, zinco e lastre di vetro per le coperture. Le cupole, che sormontano le varie aree dell'edificio, sono delimitate da una balaustra in pietra che si affaccia sul paesaggio circostante. L'ingresso principale è caratterizzato da una facciata scenica a tre arcate con due corpi aggettanti laterali, riccamente decorati da fasce orizzontali di cromie diverse e scala in marmo contornata da sfingi in pietra. La pianta è divisa in tre corpi quadrangolari collegati da una galleria centrale sormontata da una volta in ferro e vetro con lucernari, le navate laterali, invece, presentano delle colonne in ghisa che sorreggono la struttura della copertura.
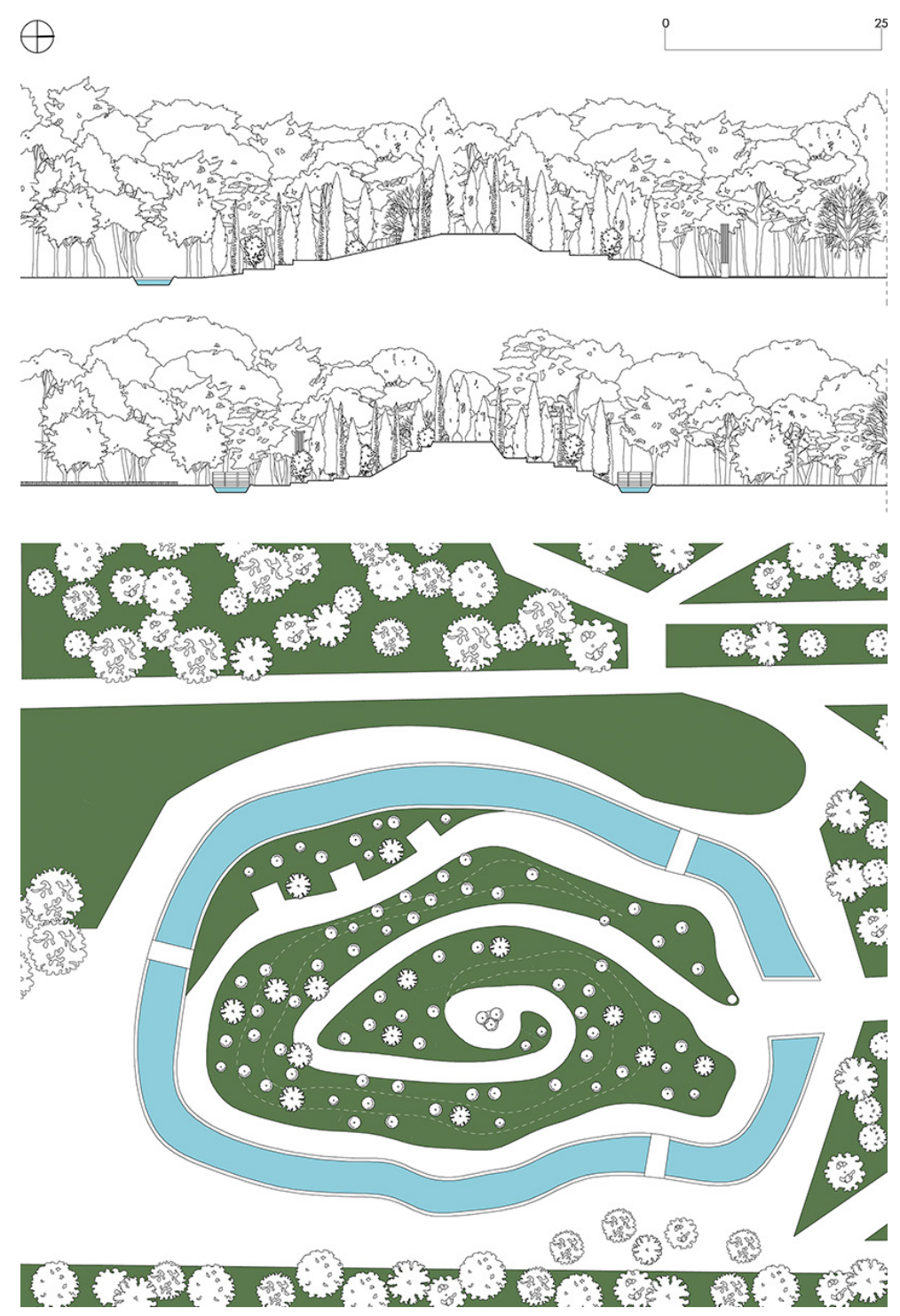
Nello stesso periodo vi fu un'altra Esposizione Internazionale, quella delle Isole Filippine del I887, che portò alla realizzazione del Palacio de Cristal, costruito per ospitare piante tropicali e il relativo completamento della Cascada. Lo scopo, prettamente funzionale, riguardava la necessità di trovare un luogo nel quale mantenere e curare alcune piante tropicali. Sia il Palazzo, owero una serra, sia il lago, per l'appigionamento d'acqua per le differenti varietà di piante, avevano la funzione di creare l'ambiente tropicale idoneo all'esposizione internazionale delle piante esotiche. Il progetto dell'edificio fu redatto dall'architetto Ricardo Velazquez Bosco che si ispirò al Crystal Palace costruito a Londra da Joseph Paxton in occasione dell'Esposizione Internazionale nel I $85 \mathrm{I}$. È formato da elementi portanti in metallo ricoperti da lastre di vetro e decorazioni ceramiche. Esternamente sono presenti diverse raffigurazioni su maiolica composte da piccole mattonelle realizzate da Daniel Zuloaga. L'edificio si compone di un basamento in lastre di granito grigio, una successiva fascia in muratura di cotto rosso e, superiormente, ampie vetrate intervallate da colonne in metallo sormontate da capitelli di ordine ionico. Tra i due livelli di copertura che caratterizzano la forma geometrica dell'intera struttura, è presente una fascia di piccole finestre in metallo e lastre di vetro. L'interno è composto da tre navate con al centro una grande cupola alta circa 25 metri su un'estensione totale dell'edificio di 60 metri in lunghezza e 30 in larghezza. L'edificio è caratterizzato da due piani il primo ipogeo, usato principalmente per servizi e spazi tecnici, il secondo epigeo al quale si accede attraverso una imponente scala che conduce a un portico aggettante sul lago antistante. Successivamente all'evento espositivo, sono state conservate sia la tipologia arborea degli Aesculus Hippocastanum, ossia gli ippocastani, che coronano il lago, sia dei Taxodium Distichum, cipressi di palude chiamati così perché le loro radici si affondano nelle acque. Con una forma irregolare lo specchio d'acqua ha una larghezza massima di circa 73 metri, ed è caratterizzato da uno getto d'acqua centrale, e a sud, da un passaggio roccioso ricoperto di edera dal quale si genera il movimento geometrico della cascata. L'impianto roccioso rappresenta, inoltre, un punto di osservazione dall'alto del lago e, a ovest, del Palazzo. Sito a una distanza di circa 8 metri e delimitato da una balaustra in pietra finemente decorata con anfore, interrotta al centro da una serie di gradini che conducono nell'acqua, la piazza antistante il Palazzo di Cristallo è l'elemento architettonico che maggiormente caratterizza il lago. Le azioni di rilievo manuale e strumentale hanno determinato una serie di inedite assonometrie costruite sia dall'alto, per una visione della copertura in ferro e vetro, sia dal basso, per l'analisi degli elementi portanti e delle murature in fondazione.

\section{Il settore sud e le architetture della memoria}

Nell'area situata più a sud del Parco vi è il Bosque del Recuerdo, una zona a verde sorta nel 2005 a seguito dell'attentato terroristico che colpì la città di Madrid e in particolare la stazione metro di Atocha, l'I I marzo del 2004, riportando 191 vittime. Con lo scopo di commemorare il tragico evento, fu prevista la creazione di un memoriale realizzato attraverso la forma a spirale di una collina colma di alberi. Infatti, il Bosque del Recuerdo presenta 192 alberi, di cui 22 olivi e 170 cipressi in ricordo delle vittime. La geometria del terreno è caratterizzata da un tumulo in terreno alto, nella parte centrale, circa 5 metri e raggiungibile attraverso un percorso pedonale segnato dai cipressi e dagli olivi, fino a raggiungere la cima dove si ergono tre cipressi. La collina è contornata da un altro percorso pedonale pianeggiante che parte dall'ingresso al complesso commemorativo segnato da una colonna scanalata con tre panchine. L'intero monumento è caratterizzato da un corso d'acqua artificiale che circonda il memoriale e ne simboleggia lo scorrere della vita.

\section{Conclusioni}

L'interesse consolidato per i parchi urbani, da tempo oggetto di numerose ricerche nel Dipartimento di Architettura e Disegno Industriale dell'Università della Campania Luigi 
Vanvitelli e nella Escuela de Arquitectura dell'Università di Alcalà, costituisce un frammento di notevole interesse per la disciplina della rappresentazione, in quanto documenta attraverso il rilievo dell'architettura e dell'ambiente i luoghi a verde nelle città europee. Di notevole importanza è risultato lo studio delle fonti archivistiche presenti nella Biblioteca di Madrid, le quali hanno costituito il punto di partenza per una conoscenza dell'area, supportato successivamente dalle indagini manuali e strumentali condotte nel Parco del Retiro. Particolare attenzione è stata dedicata alla modellazione digitale avanzata, condotta con software innovativi a basso costo, al fine di conoscere il patrimonio architettonico e culturale madrileno e, al contempo, ponendo l'attenzione alla tutela e alla successiva valorizzazione e conservazione dei luoghi.

\section{Riferimenti bibliografici}

Ariza Munoz M. C. (200I). Los jardines del Buen Retiro de Madrid. Centro Mesonero Romanos. Madrid en sus planos I622 - 2001. Ayuntamiento de Madrid: Arte Graficas Municipales, p. 24.

Chías P. (2016). Dibujo y Arquitectura. 1986-2016, 30 años de investigación/Drawing and Architecture. 1986-20 I6, 30 Years of Research. Alcalá de Henares: Colección: Monografías de Investigación, p. 420.

Chías P., Abad Balboa T. (2012). El Patrimonio fortificado. Cádiz y el Caribe: una relación transatlántica/The Fortified Heritage. Cadiz and the Caribbean: A Transatlantic Relationship. Alcalá de Henares.

Chías P., Abad Balboa T. (2018). Building for the Crown: Contracts and administration under the Spanish monarchy in the sixteenth and seventeenth centuries, the Monastery of El Escorial. In Building Knowledge, Constructing Histories, vol. I. Leiden: CRC Press, pp. 89-96

Chías P., Abad Balboa T. (2019). The lands owned by the King: Plans and drawings of the Spanish Royal Sites: Aranjuez between reality and illusion. In P. Belardi (a cura di). Riflessioni. L'arte del disegno/il disegno dell'arte. Atti del XVI Congresso dell'Unione Italiana per il Disegno, $41^{\circ}$ Convegno Internazionale dei Docenti della Rappresentazione. Perugia 19-2I settembre 2019. pp. 543-560. Roma: Gangemi Editore.

Corniello L. (2019). II disegno del Parco Reale di Tirana. Napoli: La scuola di Pitagora editrice.

Docci M., Maestri D., Gaiani M. (20I I). La scienza del Disegno. Milano: CittàStudi.

Duran Cermeno C. (2003). Jardines del Buen Retiro. Madrid: Doce Calles.

Garcia Gomez L. (20I5). El retiro paso a paso guia del parque. Madrid: Naperma.

Giordano P. (20 I6). Il disegno dei parchi urbani. Roma: Ermes Editore.

Lopez Lillo A. (2000). Arbores de Madrid. Comunidad de Madrid: Mundi Prensa.

Navascues Palacio P. (2007). Arquitectura e Ingenieria del hierro en Espana (I 8/4-1936). Madrid: El Viso e Iberdrola.

Papa L. M. et al. (2020). Un progetto di valorizzazione dei Siti Reali in Europa. II caso della Reggia di Portici in Campania. A project for the enhancement of the Royal Sites in Europe. The case of the Reggia di Portici in Campania. In Paesaggio urbano, 2, pp. 137-147.

Parrinello S. (20I3). Disegnare il Paesaggio. Esperienze di analisi e letture grafiche dei luoghi. Firenze: Edifir.

\section{Autori}

Davide Carleo, Università della Campania “Luigi Vanvitelli", davide.carleo@unicampania.it

Martina Gargiulo, Università della Campania “Luigi Vanvitelli”, martina.gargiulo@unicampania.it

Luigi Corniello, Università della Campania “Luigi Vanvitelli", luigi.corniello@unicampania.it

Michelangelo Scorpio, Università della Campania "Luigi Vanvitelli", michelangelo.scorpio@unicampania.it

Giovanni Ciampi, Università della Campania "Luigi Vanvitelli", giovanni campi@unina.it

Pilar Chías Navarro, Università di Alcalà, pilar.chias@uah.es

Per citare questo capitolo: Carleo Davide, Gargiulo Martina, Corniello Luigi, Scorpio Michelangelo, Ciampi Giovanni, Chías Navarro Pilar (2021) II linguaggio dell'architettura funzionale e della memoria nel Parco del Retiro a Madrid/The language of functional architecture and memory in the Retiro Park in Madrid. In Arena A., Arena M., Mediati D., Raffa P. (a cura di). Connettere. Linguaggi Distanze Tecnologie. Atti del $42^{\circ}$ Convegno Internazionale dei Docenti delle Discipline della Rappresentazione/Connecting. Languages Distances Technologies. Proceedings of the $42^{\text {th }}$ International Conference of Representation Disciplines Teachers. Milano: FrancoAngeli, pp. 329-352 


\title{
The Language of Functional Architecture and Memory in the Retiro Park in Madrid
}

\author{
Davide Carleo \\ Martina Gargiulo \\ Luigi Corniello \\ Michelangelo Scorpio \\ Giovanni Ciampi \\ Pilar Chías Navarro
}

\section{Abstract}

The research presents the results of the architectural and environmental survey campaign in the Retiro Park in Madrid, studying, through architectural drawing, the historical and formal evolution up to the current configuration. It was of considerable interest to retrace, with the aid of archive images, the salient phases of the construction through the personalities and events of the palace. Of great importance in the knowledge of this evolution is the study of the historical plans of the city of Madrid and how the morphological and topographical change of the park can be seen in them. The study involved the Casita del Pescador, the Templete del Retiro, the Estanque Grande, an early water reservoir used for both the palace and the park, the Palacio de Velazquez, the Palacio de Cristal e la Cascada, and the Bosque del Recuerdo, a hill built in 2004 following the terrorist attack in Madrid to commemorate the 191 victims of the massacre. The final objective of the study is to document the architecture of the past by means of surveys and digital models, and to lay the foundations for protection and regeneration of the structures and greenways.

Keywords

survey, modelling, representation, park, Spain.

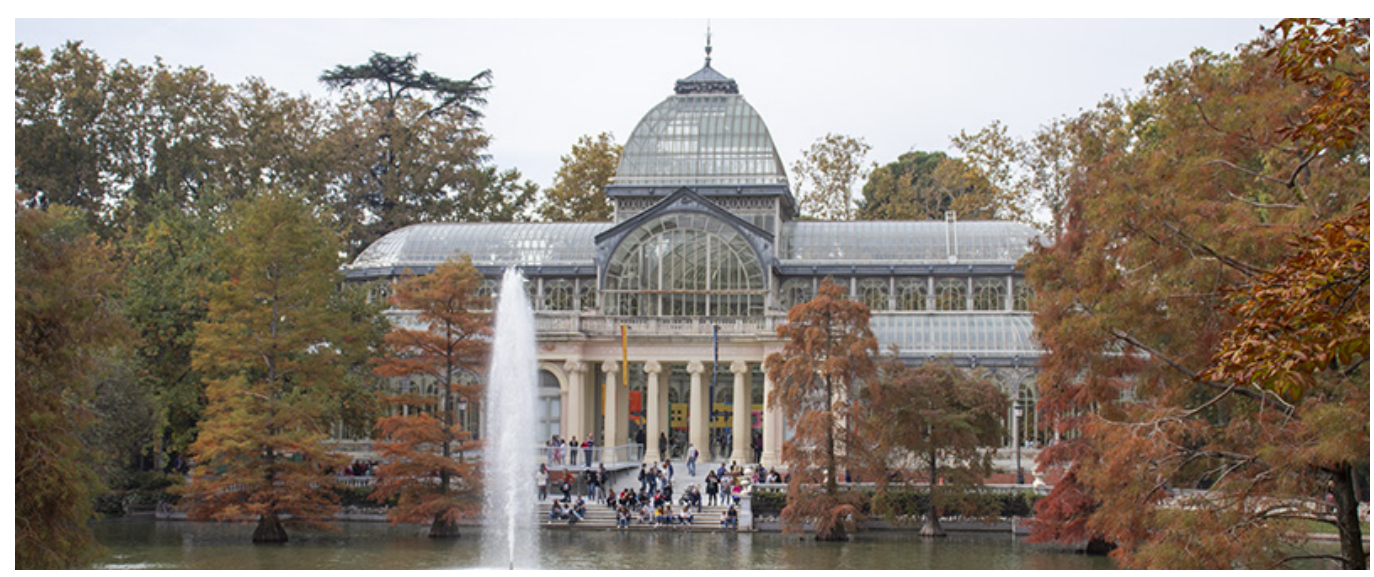




\section{Introduction}

The research intends to focus on the Retiro Park in Madrid, and specifically on the vegetation and architectural systems, studying, through architectural design, the evolution up to the present configuration. The construction period dates back to 1630, the year in which some of the areas of which the Park is still composed were strongly desired by the King of Austria. Archival studies have made it possible to analyse the formal and morphological transformation of what would later become one of the most important areas of the city.

The original project envisaged a series of architectures around a Palace with its own garden: today what remains of the original building is called Casòn del Buen Retiro while the garden has evolved over the centuries. It was of considerable interest to retrace, with the help of archive images, the salient phases of the construction through the characters and events of the Palace. Of great importance in the knowledge of this evolution is the study of the historical plans of the city of Madrid and how the morphological and topographical change of the Park can be seen in them. In 1620 the Estanque Grande was built, an initial water tank used as a reservoir for both the Palace and the Park, which was later transformed into a meeting place for the nobility where they carried out water activities with boats. At the beginning of the following century, around I 70 I, following the stylistic dictates of the French Garden, the Jardin del Parterre was designed, modified during the War of Independence. With the arrival in Madrid of the lineage of the Bourbons, tree species and new areas were added, which were not made accessible

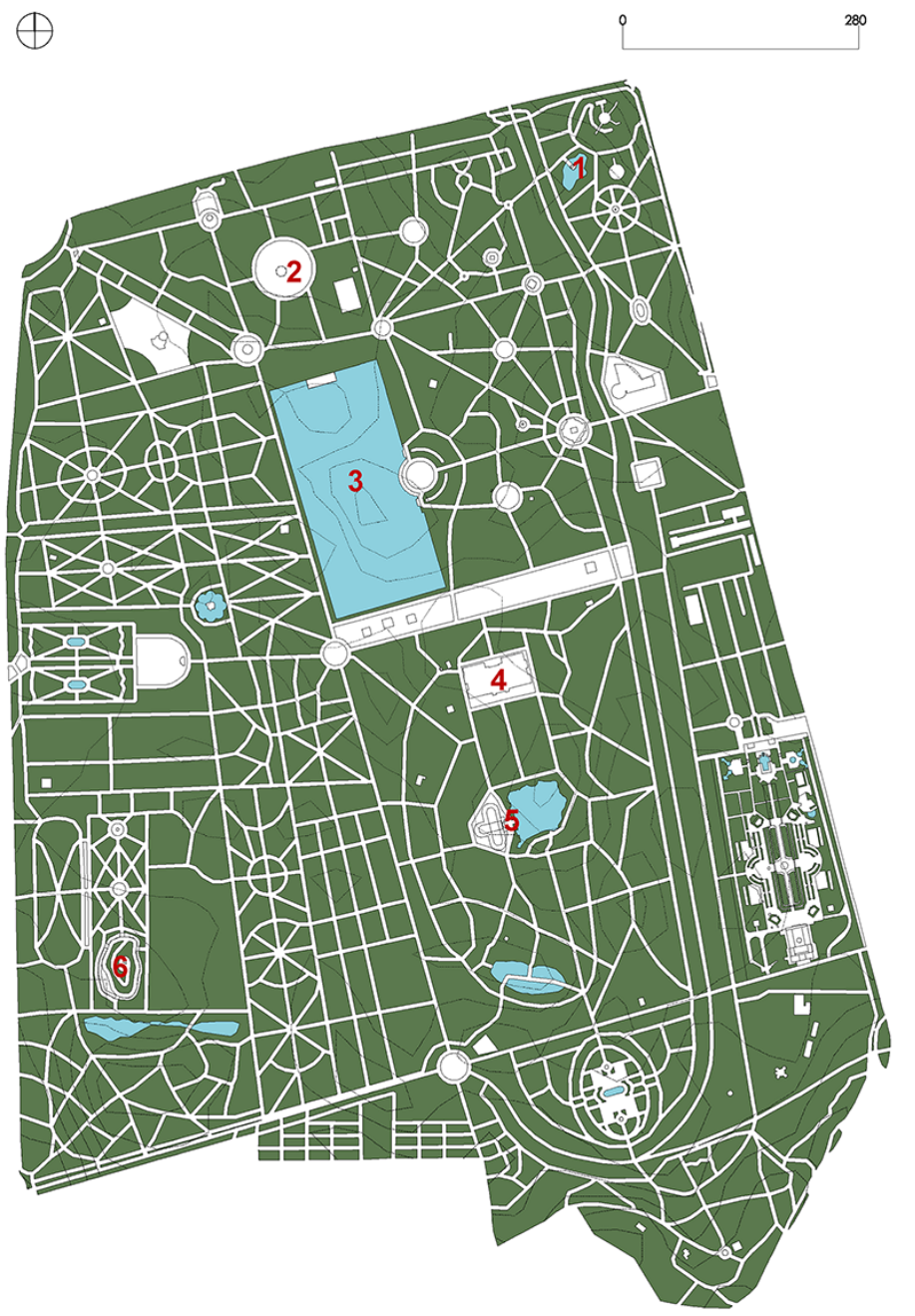


$\otimes$
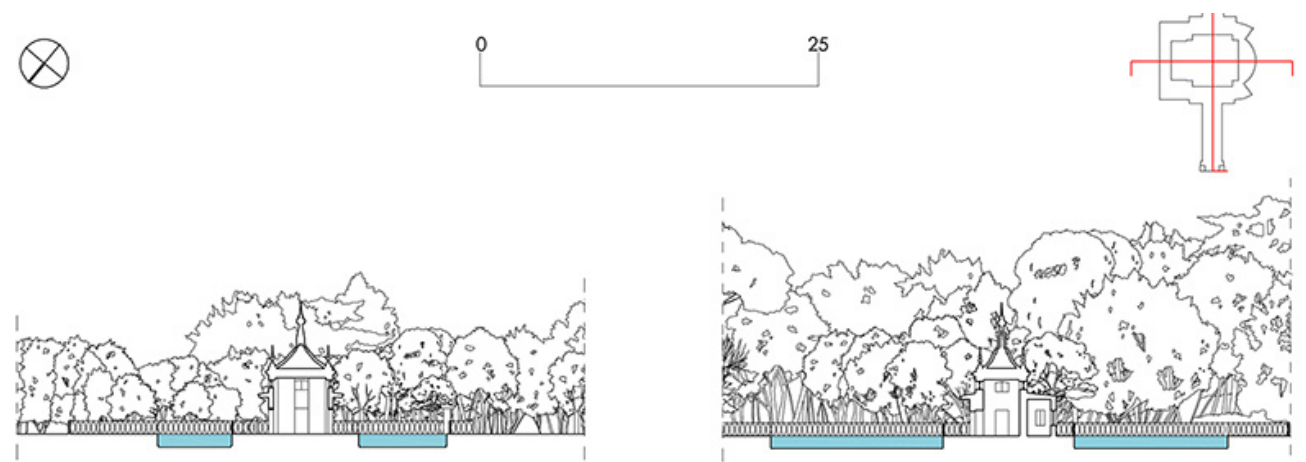

Fig. 2. The Retiro Park

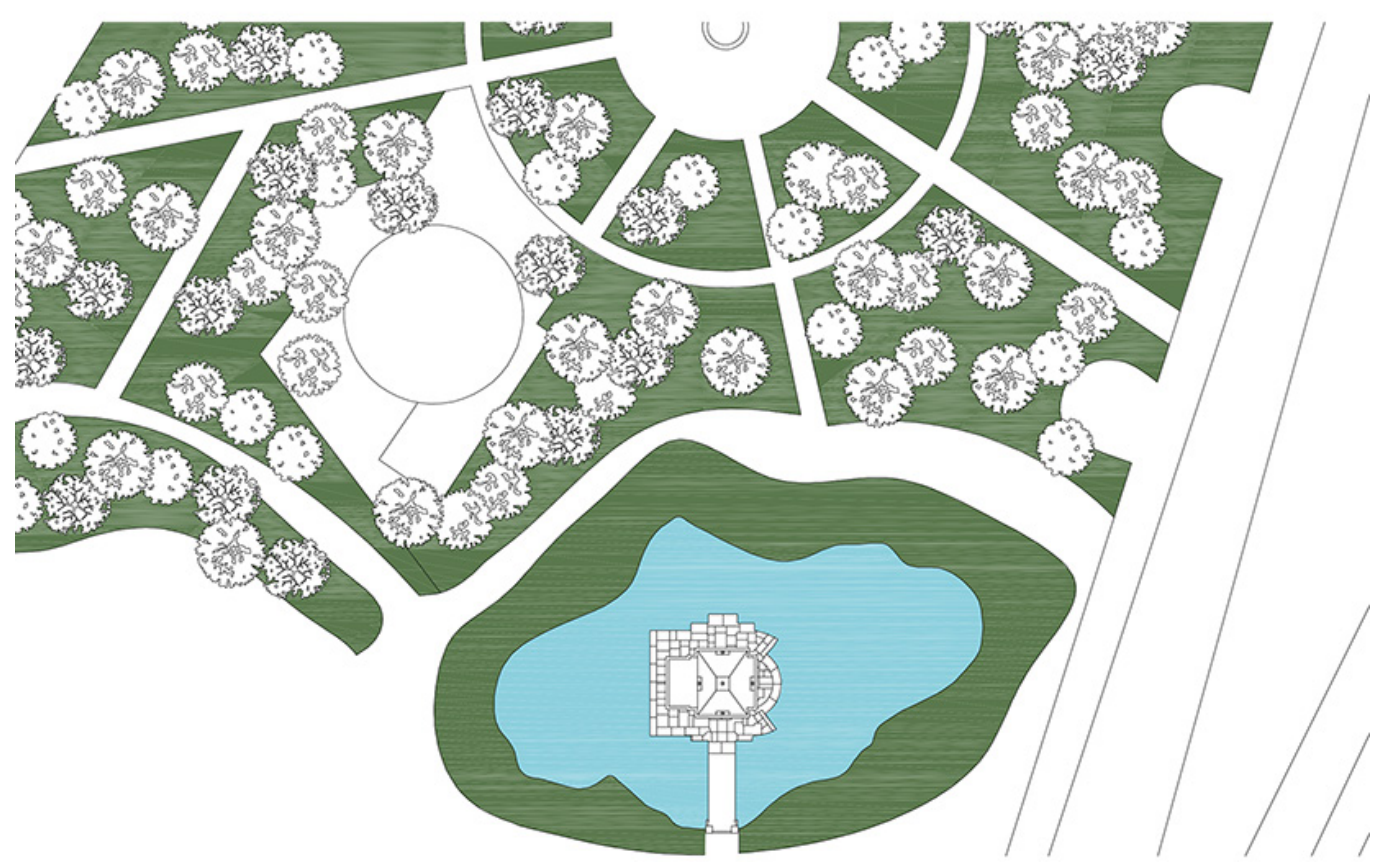

Fig. 3. The Retiro Park

in Madrid, the Casita de

Pescador, axonometry

from below.

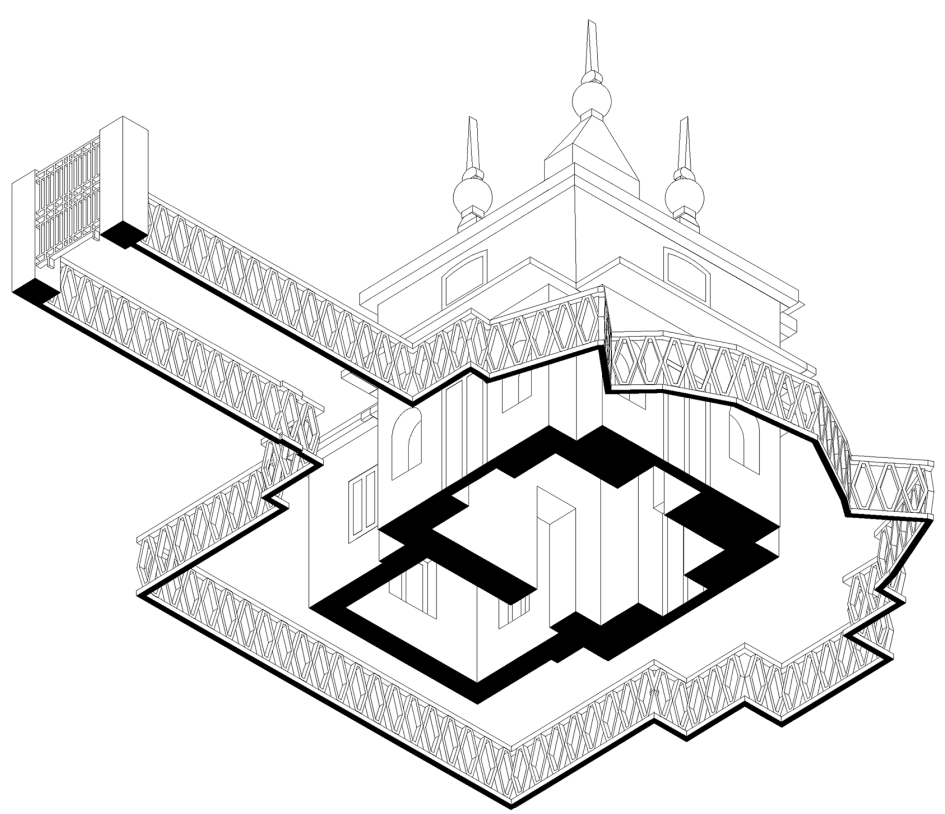


to the public until 1767, when Charles III made them accessible to the public on condition that they respected certain rules and territorial limits exclusive to the Crown. In the 19th century, the War of Independence caused considerable damage to the Park, but there are numerous historical plates from that period that illustrate the intense restoration work that took place with the addition of further architectural elements. Subsequently, the management of the Park came under the control of the Municipality of Madrid, which declared it a public park.

In the last years of the 19th century, it was designated as a venue for important international exhibitions, which required the addition of a series of exhibition pavilions and green spaces, such as the Palacio de Velazquez and the Palacio de Cristal, designed as a greenhouse and located at the base of a splendid waterfall called the Cascada, which was initially used to irrigate the vegetation of the Park. Until the first decades of the 20th century, first the architect José Urioste y Velada and later the municipal architect Luis Bellido were responsible for the construction of the new enclosure and the building of new entrance gates.

The 20th century also saw the construction of several memorials, including one dedicated to Alfonso XII in the Estanque Grande and another to the historic gardener Cecilio Rodriguez.

The Bosque del Recuerdo, a hill built in 2004 after the terrorist attack in Madrid to commemorate the 191 victims of the massacre, was built recently.

\section{The northern sector and the original architectures}

The survey of the architecture and green systems of the Retiro Park in Madrid constitutes a process of knowledge of elements inherited from the past and proposes a systemic study, with a graphic and geometric survey of the structures. Through a critical reflection on architecture, by means of a graphic investigation of the disciplinary sources of design, with attention to the themes of form, structure, innovation and representation, it aims to place, the drawing of some archive documents and the survey of the current state of the structures and vegetation.

The study presents the results of the survey carried out between October 2019 and February 2020, taking into account the orientation of the Park and following the route from North to South.

The Casita del Pescador, located in the north-eastern area of the Park, was built at the beginning of the 19th century during the monarchy of Fernando VII after the entire park was damaged during the War of Independence. The King proposed the reconstruction of the destroyed elements and introduced new ones to revive the value of the park but also for personal needs. The Casita del Pescador was built for the King's free time, as a place of recreation and a place to fish. Over the years it has undergone several restorations, including one in 1959 that changed its use to a library for storing gardening books. Abandoned for several years, it was restored in early 2000 and now houses an information centre for pet adoption. Originally designed by the architect Isidro González Velázquez, it is approximately 7 metres long, 6 metres wide and 10 metres high and is surrounded by a small artificial lake. The façade has pink stucco, Pompeian-style ornaments and paintings, and two niches on each side where statues used to stand. The interior is divided into a main room and a modest side room, the ceilings are frescoed with geometric motifs and allegorical figures and there are several decorative stucco ornaments. Access to the Casita is via a wooden walkway with a balustrade suspended over the water basin. The roof has a traditional Madrilenian zinc spire system topped by a metal sphere. The islet is located in the middle of the lake, which is about I metre deep. Until the 20th century, the outer fence was made of wooden planks, but at the end of the First World War it was replaced by a stronger wrought iron fence decorated with the same geometric motif as the terrace railing, but at a lower height. In the northern area of the park is the Templete del Retiro, 
Fig. 4. The Retiro Park in Madrid, Templete del Retiro, roofs plan, section (right).

$\oplus$
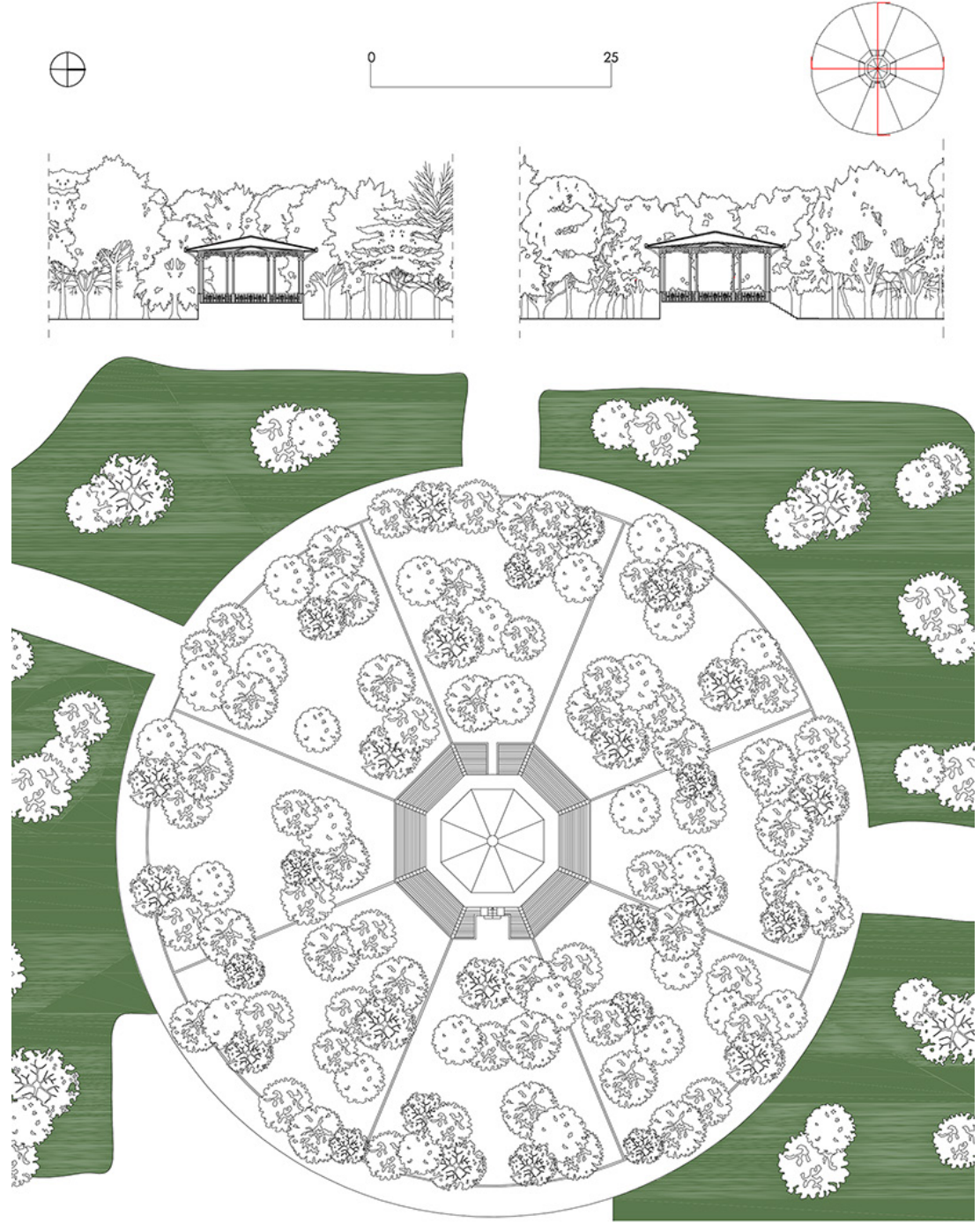

Fig. 5. The Retiro Park in

Madrid, the Templete de

Retiro, axonometry from

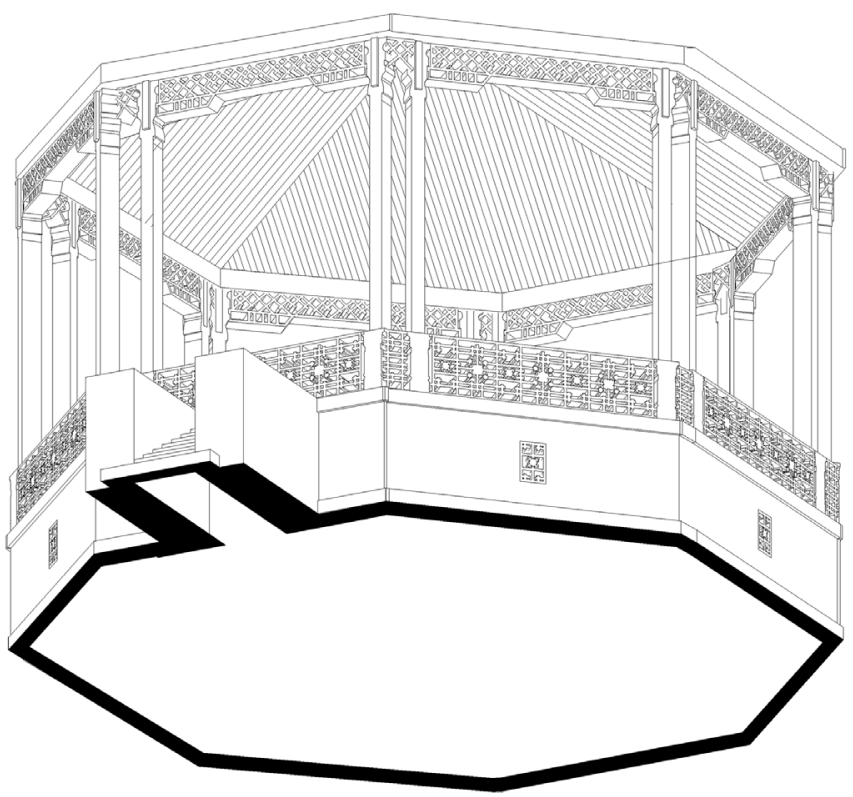


which was built in 1925 on commission of the Municipality of Madrid with a project drawn up by the architect Luis Bellido. The structure is characterised by an octagonal plan with 4.60 metres per side and a height of approximately 10 metres; the floor is higher than the ground in order to amplify the sound through an underground system of solids and voids. The lower external wall face is marked by a small opening, closed by an ornamental iron grille on each side of the octagon, while at the back, there is a small door to provide access for maintenance work. The octagon is surrounded by a richly decorated iron balustrade and at the end of each side there is an ornate iron pillar supporting the roof. The roof is made of iron, while the interior is covered with wooden slats to ensure proper sound amplification. The Templete del Retiro has contemporary examples in various parks and gardens in Europe, with structures built from the beginning of the nineteenth century for musical performances. Similarly constructed and often having the same shape for acoustic reasons, these structures are a recurring feature.

In 1635, however, the Estanque Grande built by Cristóbal de Aguilera was completed and subsequently donated by the Duke of Olivares to King Felipe IV. It was conceived as a large water reservoir that could guarantee a water supply to both the Royal Palace and the fountains in the gardens. The original design included viewing towers on the four sides of the fountain to channel the water and distribute it to the different areas of the
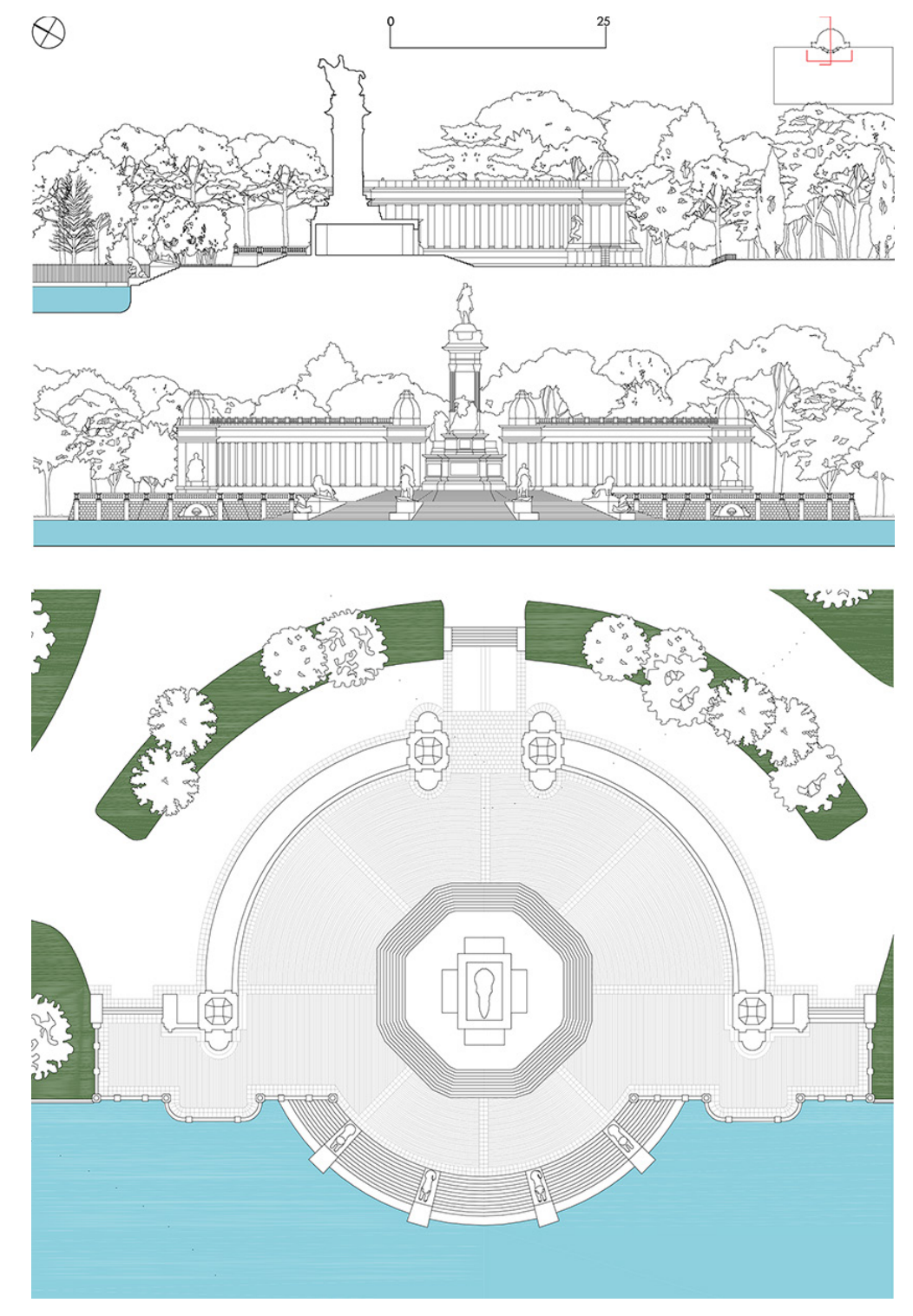
$\varnothing$
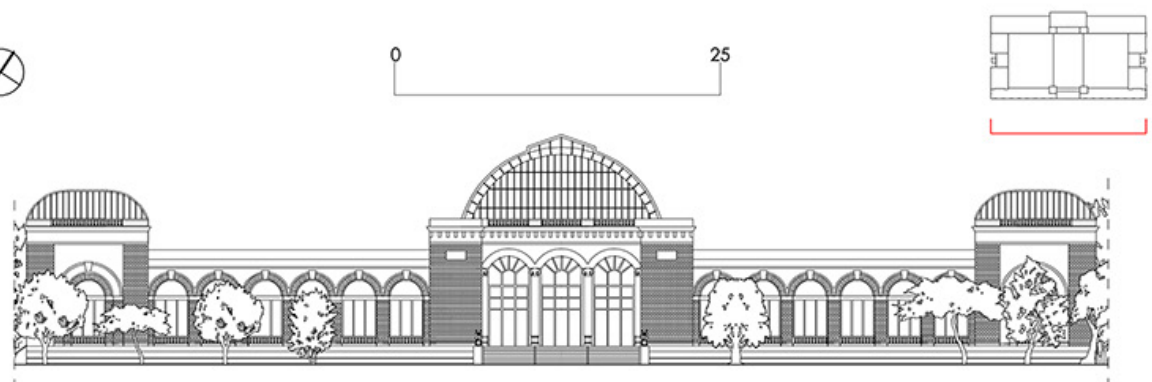

Fig. 7. The Retiro Park in
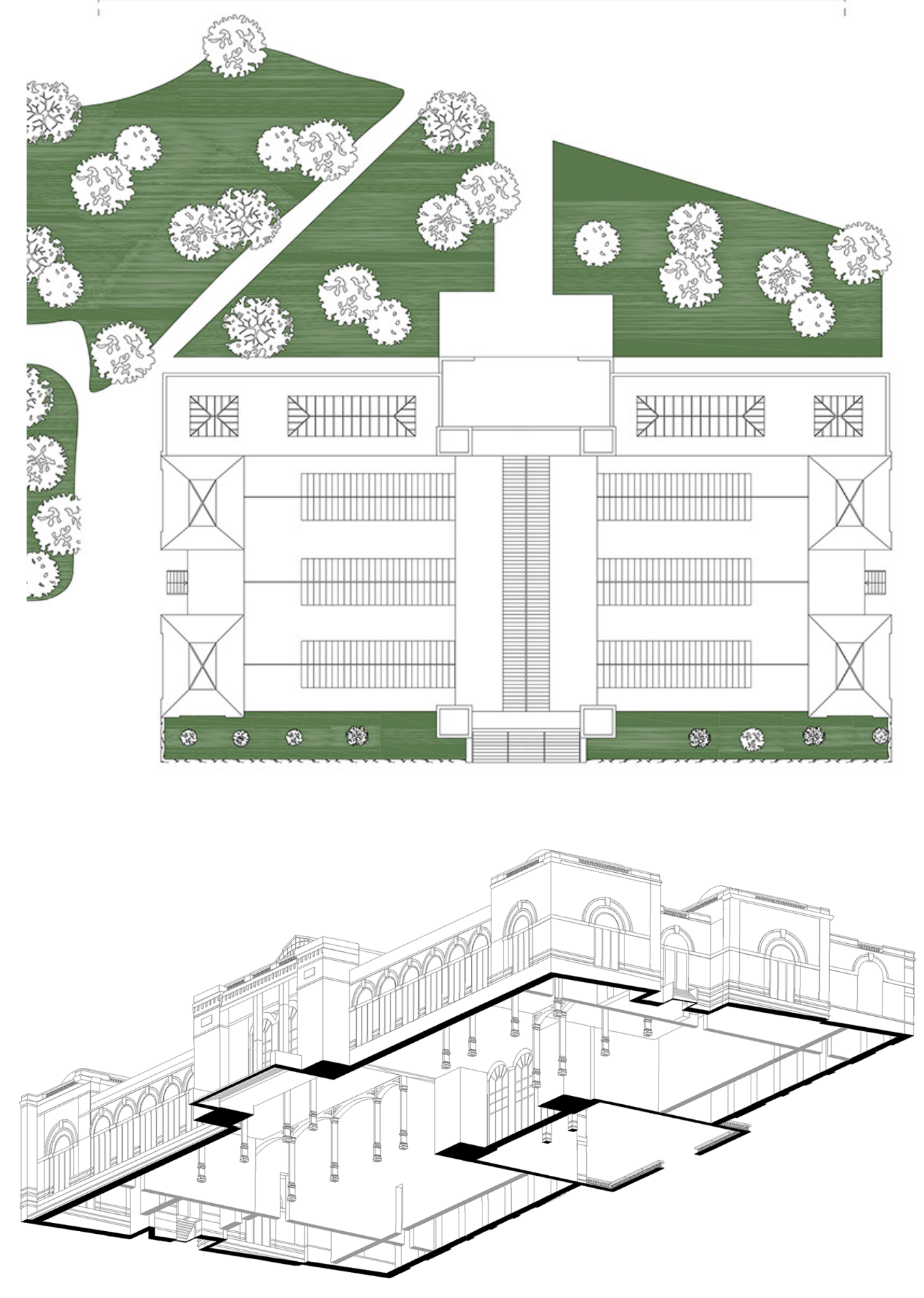
Park. During the War of Independence, the Retiro Park was used as the headquarters of Napoleon's troops and the Estanque Grande suffered a great deal of damage. After the war, Ferdinand VII restored the original state of the building and proposed a stylistic remodelling by the architect Isidro González Velázquez. To the east, on the side where the Monument to Alfonso XII currently stands, three bodies decorated with Chinese motifs were built; to the south, the Egyptian Fountain was constructed and in the centre of the main fountain a large column with a statue of Ferdinand VII. The entire complex was opened to the public at the behest of his daughter Isabel II, with the corresponding permission for navigation. Later, after the years of the Revolution, the whole park was taken over by the municipality and with it the Estanque Grande. The structure, with a width of about 125 metres, a length of 250 and a maximum depth of about 1.80, is surrounded by the presence of different species of trees populated by a rich variety of fauna.

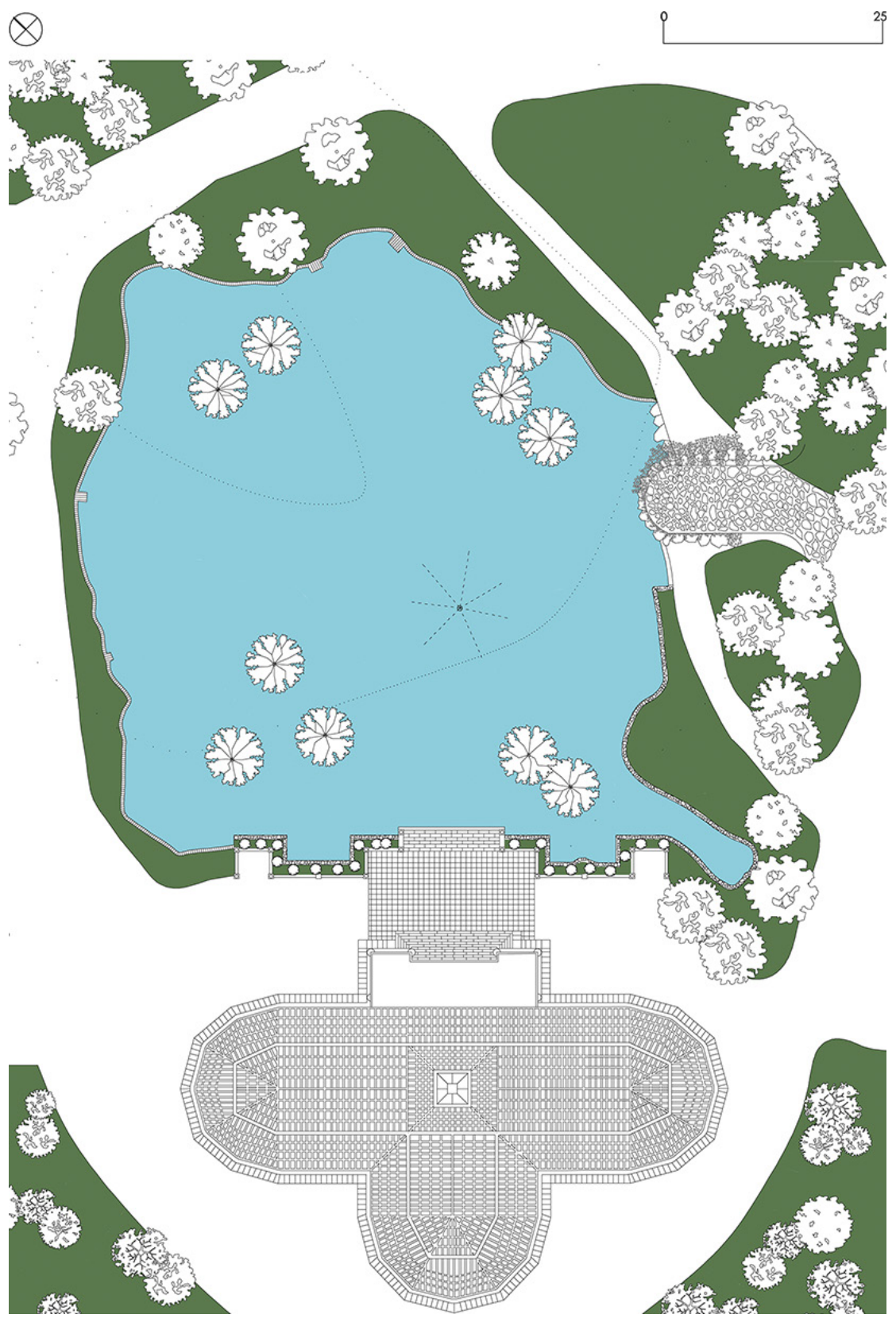


Fig. 10.The Retiro Park

in Madrid, the Palacio de Cristal and the Cascada, section A-A' (top), section $B-B^{\prime}$ (bottom).
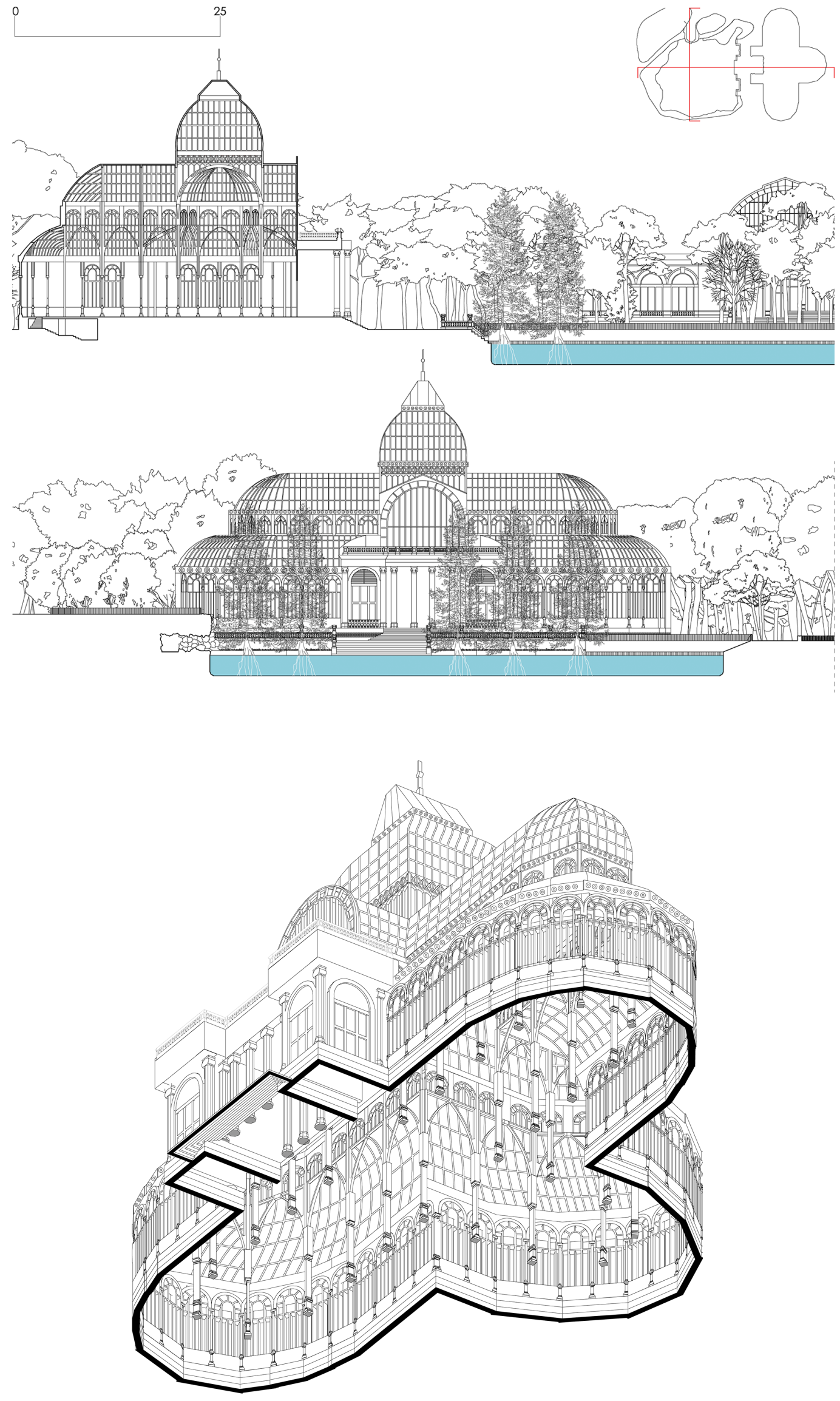


\section{The central sector and functional architectures}

In the central area of the park is the Palacio de Velazquez, built under the reign of Alfonso XII in I883, to a design by the architect Ricardo Velazquez Bosco under the technical direction of Alberto del Placio, while Daniel Zuloaga and Bernardo Asins were responsible for constructing and assembling the iron and glass roof. The building was constructed for the 1883 International Exhibition of Ceramics, Glass and Natural Waters. It is rectangular in shape, with the longest side facing south measuring about 80 metres and the shortest side about 30 metres, with a height of about 20 metres. The façades are characterised by masonry in different shades of colour, ceramics with geometric and plant motifs to decorate the arches, stucco for the cornices, iron for the structure of the domes and, finally, zinc and sheets of glass for the roofs. The domes, which surmount the various areas of the building, are bordered by a stone balustrade overlooking the surrounding landscape. The main entrance is characterised by a scenic three-arched façade with two projecting side bodies, richly decorated with horizontal bands of different colours and a marble staircase surrounded by stone sphinxes. The plan is divided into three quadrangular bodies connected by a central gallery surmounted by an iron and glass vault with skylights, while the side naves have cast iron columns supporting the roof structure.
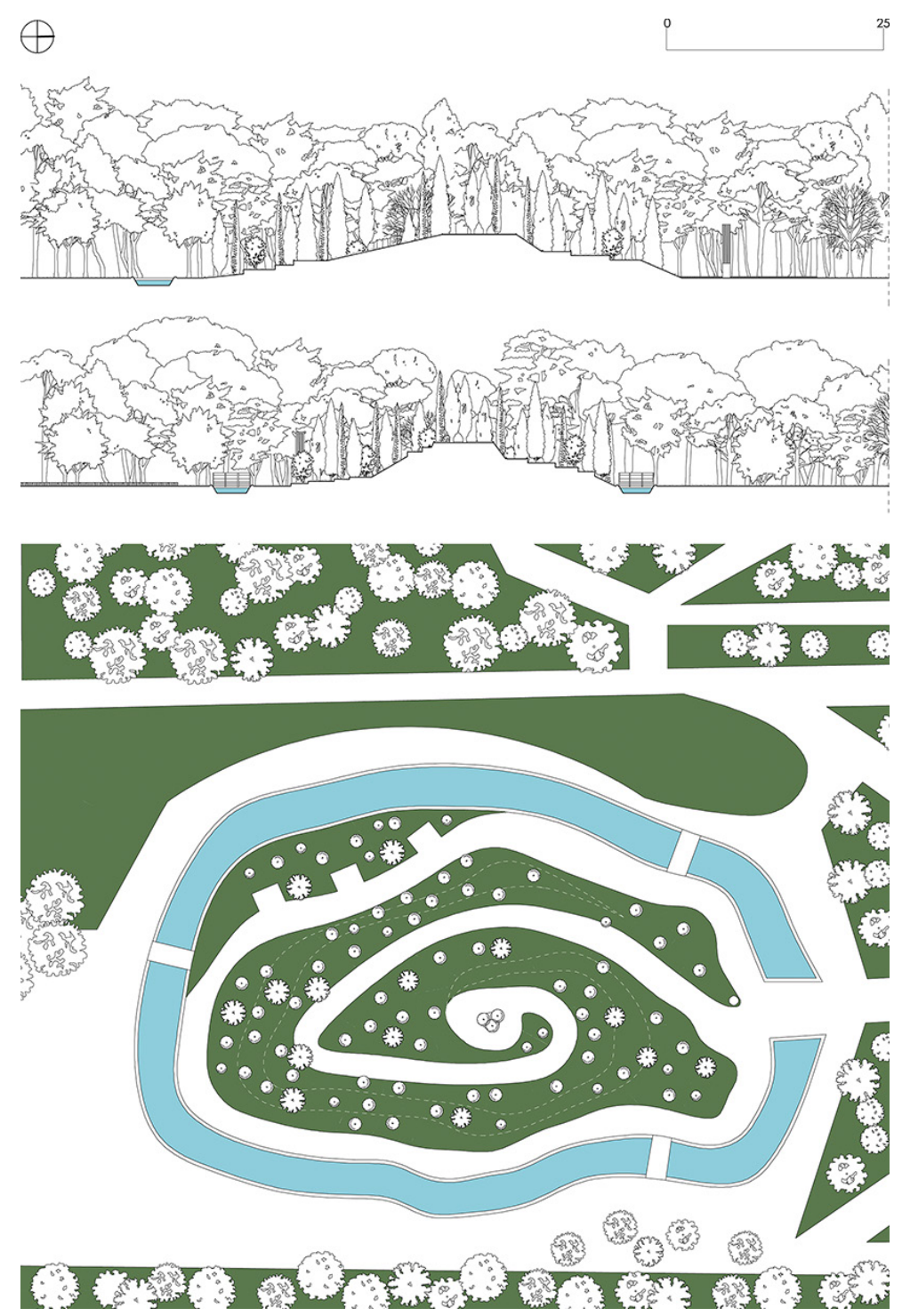
At the same time there was another International Exhibition, that of the Philippine Islands in 1887, which led to the construction of the Palacio de Cristal, built to house tropical plants and the completion of the Cascada. The purpose, purely functional, concerned the need to find a place in which to maintain and care for certain tropical plants. Both the Palais, a greenhouse, and the lake, for the supply of water for the different plant varieties, were intended to create a tropical environment suitable for the international exhibition of exotic plants. The building was designed by the architect Ricardo Velazquez Bosco, who was inspired by the Crystal Palace built in London by Joseph Paxton for the International Exhibition in 185I. It consists of metal supporting elements covered with glass plates and ceramic decorations. On the outside, there are several representations on majolica composed of small tiles made by Daniel Zuloaga. The building consists of a basement made of grey granite slabs, a subsequent band of red terracotta masonry and, above, large windows interspersed with metal columns surmounted by lonic capitals. Between the two levels of roofing, which characterise the geometric form of the entire structure, there is a band of small metal and glass windows. The interior consists of three naves with a large dome at the centre, about 25 metres high with a total extension of the building of 60 metres in length and 30 metres in width. The building has two floors, the first hypogeal, used mainly for services and technical spaces, and the second epigeal, accessed by an imposing staircase leading to a portico overlooking the lake. After the exhibition, the tree type of the Aesculus Hippocastanum, i. e. horse chestnuts, which crown the lake, and the Taxodium Distichum, marsh cypresses so called because their roots sink into the water, have been preserved. With an irregular shape, the lake has a maximum width of about 73 metres and is characterised by a central water jet and, to the south, by an ivy-covered rocky passage from which the geometric movement of the waterfall is generated. The rock formation also provides a high vantage point for viewing the lake and, to the west, the Palace. Located at a distance of about 8 metres and bordered by a stone balustrade finely decorated with amphorae, interrupted in the middle by a series of steps leading into the water, the square in front of the Crystal Palace is the architectural element that most characterises the lake. The manual and instrumental survey work has resulted in a series of unusual axonometries constructed both from above, to view the iron and glass roof, and from below, to analyse the load-bearing elements and the masonry in the foundations.

\section{The southern sector and the architecture of memory}

In the south of the park is the Bosque del Recuerdo, a green area created in 2005 following the terrorist attack that struck the city of Madrid and in particular the Atocha metro station on II March 2004, claiming 191 victims. In order to commemorate the tragic event, a memorial was created in the form of a spiral-shaped hill filled with trees. In fact, the Bosque del Recuerdo has 192 trees, including 22 olive trees and 170 cypresses in memory of the victims. The geometry of the terrain is characterised by a mound of soil about 5 metres high in the central part, reached by a footpath marked by cypresses and olive trees, up to the top where three cypresses stand. The hill is bordered by another flat pedestrian path from the entrance to the memorial complex marked by a fluted column with three benches. The entire memorial is characterised by an artificial watercourse that surrounds the memorial and symbolises the flow of life.

\section{Conclusions}

The consolidated interest in urban parks, which has long been the subject of numerous research projects at the Department of Architecture and Industrial Design of the University of Campania Luigi Vanvitelli and the Escuela de Arquitectura of the University of Alcalà, constitutes a fragment of considerable interest for the discipline of representation, as 
it documents green spaces in European cities through the survey of architecture and the environment. Of considerable importance was the study of the archival sources in the Library of Madrid, which constituted the starting point for a knowledge of the area, subsequently supported by the manual and instrumental surveys conducted in the Retiro Park. Particular attention was paid to advanced digital modelling, carried out with innovative low-cost software, in order to get to know Madrid's architectural and cultural heritage, while at the same time focusing on the protection and subsequent enhancement and conservation of the sites.

\section{References}

Ariza Munoz M. C. (200 I). Los jardines del Buen Retiro de Madrid. Centro Mesonero Romanos. Madrid en sus planos I 622 - 200 I. Ayuntamiento de Madrid: Arte Graficas Municipales, p. 24.

Chías P. (2016). Dibujo y Arquitectura. 1986-2016, 30 años de investigación/Drawing and Architecture. 1986-2016, 30 Years of Research. Alcalá de Henares: Colección: Monografías de Investigación, p. 420.

Chías P., Abad Balboa T. (2012). El Patrimonio fortificado. Cádiz y el Caribe: una relación transatlántica/The Fortified Heritage. Cadiz and the Caribbean: A Transatlantic Relationship. Alcalá de Henares.

Chías P., Abad Balboa T. (2018). Building for the Crown: Contracts and administration under the Spanish monarchy in the sixteenth and seventeenth centuries, the Monastery of El Escorial. In Building Knowledge, Constructing Histories, vol. I. Leiden: CRC Press, pp. 89-96.

Chías P., Abad Balboa T. (2019). The lands owned by the King: Plans and drawings of the Spanish Royal Sites:Aranjuez between reality and illusion. In P. Belardi (a cura di). Riflessioni. L'arte del disegno/il disegno dell'arte. Atti del XVI Congresso dell'Unione Italiana per il Disegno, $41^{\circ}$ Convegno Internazionale dei Docenti della Rappresentazione. Perugia 19-21 settembre 2019, pp. 543-560. Roma: Gangemi Editore.

Corniello L. (2019). II disegno del Parco Reale di Tirana. Napoli: La scuola di Pitagora editrice.

Docci M., Maestri D., Gaiani M. (20I I). La scienza del Disegno. Milano: CittàStudi.

Duran Cermeno C. (2003). Jardines del Buen Retiro. Madrid: Doce Calles.

Garcia Gomez L. (20 I5). El retiro paso a paso guia del parque. Madrid: Naperma.

Giordano P. (20 I 6). I/ disegno dei parchi urbani. Roma: Ermes Editore.

Lopez Lillo A. (2000). Arbores de Madrid. Comunidad de Madrid: Mundi Prensa.

Navascues Palacio P. (2007). Arquitectura e Ingenieria del hierro en Espana ( 8 / 4- | 936). Madrid: El Viso e Iberdrola.

Papa L. M. et al. (2020). Un progetto di valorizzazione dei Siti Reali in Europa. II caso della Reggia di Portici in Campania. A project for the enhancement of the Royal Sites in Europe. The case of the Reggia di Portici in Campania. In Paesaggio urbano, 2, pp. I37-147.

Parrinello S. (20|3). Disegnare il Paesaggio. Esperienze di analisi e letture grafiche dei luoghi. Firenze: Edifir.

\footnotetext{
Authors

Davide Carleo, Università della Campania "Luigi Vanvitelli", davide.carleo@unicampania.it

Martina Gargiulo, Università della Campania “Luigi Vanvitelli”, martina.gargiulo@unicampania.it

Luigi Corniello, Università della Campania “Luigi Vanvitelli", luigi.corniello@unicampania.it

Michelangelo Scorpio, Università della Campania "Luigi Vanvitelli", michelangelo.scorpio@unicampania.it

Giovanni Ciampi, Università della Campania "Luigi Vanvitelli", giovanni campi@unina.it

Pilar Chías Navarro, Università di Alcalà, pilar.chias@uah.es
}

To cite this chapter: Carleo Davide, Gargiulo Martina, Corniello Luigi, Scorpio Michelangelo, Ciampi Giovanni, Chías Navarro Pilar (202I). II linguaggio dell'architettura funzionale e della memoria nel Parco del Retiro a Madrid/The language of functional architecture and memory in the Retiro Park in Madrid. In Arena A., Arena M., Mediati D., Raffa P. (a cura di). Connettere. Linguaggi Distanze Tecnologie. Atti del $42^{\circ}$ Convegno Internazionale dei Docenti delle Discipline della Rappresentazione/Connecting. Languages Distances Technologies. Proceedings of the $42^{\text {th }}$ International Conference of Representation Disciplines Teachers. Milano: FrancoAngeli, pp. 329-352. 